University of Tennessee Law

Legal Scholarship Repository: A Service of the Joel A. Katz Library

UTK Law Faculty Publications

8-2016

Attorneys, Document Discovery, and Discipline

Paula Schaefer

Follow this and additional works at: https://ir.law.utk.edu/utklaw_facpubs

Part of the Law Commons 


\title{
ARTICLES
}

\section{Attorneys, Document Discovery, and Discipline}

\author{
PAULA SCHAEFER $*$
}

"[A]n attorney's ethical duty to advance the interests of his client is limited by an equally solemn duty to comply with the law and the standards of professional conduct."1

\begin{abstract}
Most attorneys who engage in document discovery misconduct in civil cases in federal court do not face professional discipline. This is the case even though professional conduct rules prohibit every aspect of discovery abuse, from failure to produce requested documents to spoliation of evidence. Further, most federal courts have their own disciplinary systems, and judges and lawyers alike have an ethical obligation to report attorney misconduct. Though the tools are in place, the discipline system is not being used to address pervasive document discovery misconduct.

This Article argues that federal courts could make more effective use of attorney discipline systems to improve document discovery in civil cases. In making the case for reform, this Article explains the appropriate cases for discipline referrals, how behavioral legal ethics research should influence judges to consistently turn to the discipline system, and the advantages of discipline over sanctions alone. The Article concludes by considering three different settings in which document discovery discipline reform could be achieved: at the judgelevel, court-level, and nationally. This discussion considers ways to implement change in each setting and the reasons some avenues may be more effective than others.
\end{abstract}

\footnotetext{
* Associate Professor of Law, University of Tennessee College of Law. Thanks to Clifford Shirley, Alex Long, Cassandra Burke Robertson, and Ben Barton for providing helpful suggestions on prior drafts of this Article. Thanks also to participants in workshops at the Southeastern Association of Law Schools Annual Conference and the University of Tennessee College of Law for their feedback on the Article. Finally, thank you to Christopher John and Andrew Tucker for excellent research assistance. (c) 2017, Paula Schaefer.

1. Jerman v. Carlisle, McNellie, Rini, Kramer \& Ulrich LPA, 559 U.S. 573, 600 (2010) (quoting Nix v. Whiteside, 475 U.S. 157, 168 (1986)).
} 
TABLE OF CONTENTS

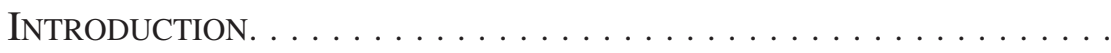

I. Attorney Misconduct in Federal Civil Document Discovery Practice AND the Availability and Use of SANCTIONS TO COMBAT IT $\ldots \ldots \ldots \ldots \ldots \ldots \ldots$

A. OVERBROAD REQUESTS FOR PRODUCTION OF DOCUMENTS . . . . . . . . . . . . . . .

B. A LACK OF TRANSPARENCY REGARDING THE SPECIFIC BASIS FOR OBJECTIONS AND CONCERNING DOCUMENTS

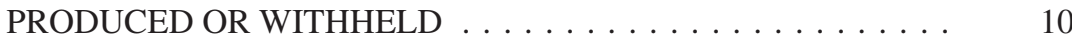

C. NEGLIGENT OR INTENTIONAL SPOLIATION OF EVIDENCE . . . . . . . . . . . . . . . . . . . .

D. SANCTIONING ATTORNEY AND CLIENT CONDUCT IN DOCUMENT DISCOVERY

II. Professional Conduct Rules and Discipline

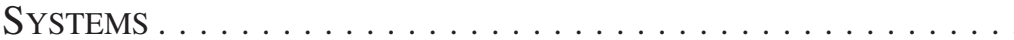

III. The (Apparently) Rare Use of the Discipline System to AdDRESS Discovery Misconduct In FEDERAL

COURT

IV. BARriers to AtTORnEys AND Judges RePorting COUNSEL'S DisCOVERY MisCONDUCT TO DisCIPLINARY AUTHORITIES . . . .
A. EXPLANATIONS FOR ATTORNEYS UNDERREPORTING MISCONDUCT BY OPPOSING COUNSEL . . . . . . . . . . . .
B. EXPLANATIONS FOR JUDGES UNDERREPORTING ATTORNEY DISCOVERY MISCONDUCT

V. The Case for Appropriate, Consistent Use of the Discipline System to AdDRESS DOCUMENT Discovery

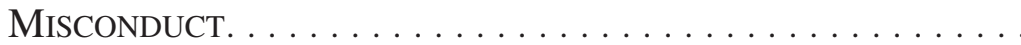

A. APPROPRIATE USE OF THE DISCIPLINE SYSTEM: WHICH DISCOVERY CONDUCT SHOULD (AND SHOULD NOT) RESULT IN DISCIPLINE? . . . . . . . . . . . . . . . . 25

B. CONSISTENCY AND BEHAVIORAL LEGAL ETHICS . . . . . 28 
C. ADVANTAGES OF DISCIPLINE OVER SANCTIONS

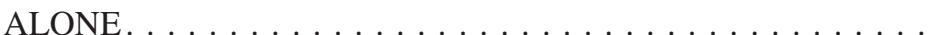

VI. Discipline-Focused Reforms that MAY IMPROVE

Discovery Conduct in Federal Civil CASES . . . . . . . . . . .

A. JUDGE-LEVEL REFORMS: SCHEDULING CONFERENCES AND ORDERS AND ADDRESSING MISCONDUCT WHEN IT

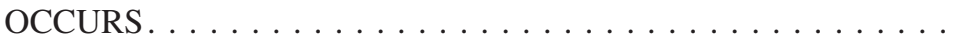

1. Scheduling Conferences And Orders . . . . . . . . . . .

2. Addressing Discovery Misconduct When It Occurs . . . . .

B. COURT-LEVEL REFORMS: JUDICIAL EDUCATION, ATTORNEY EDUCATION, AND AMENDMENTS TO LOCAL

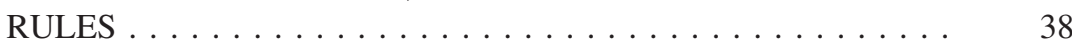

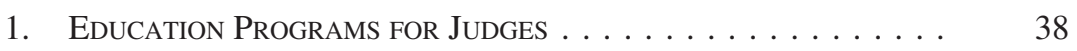

2. Remedial Discovery Education Programs to Address

LAWYeR Misconduct. . . . . . . . . . . . . . . . .

3. AmEndments to Local Rules that Facilitate Discovery Discipline AND EDUCATION . . . . . . . . . . . . . .

C. FEDERAL JUDICIARY-WIDE REFORM: ADOPTION OF A MANDATORY DISCIPLINE REFERRAL RULE IN THE CODE OF CONDUCT FOR U.S. JUDGES . . . . . . . . . . . . . . . .

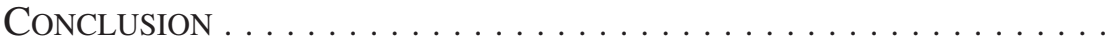

\section{INTRODUCTION}

Attorney misconduct in document discovery ${ }^{2}$ in federal court is pervasive. ${ }^{3}$ Misconduct in this context includes violations of the Federal Rules of Civil Procedure (FRCP), court orders governing discovery, and the common law duty of preservation. ${ }^{4}$ The problem permeates civil litigation to such a degree that it difficult to quantify with precision. Disputes about whether an opponent has met its discovery obligations are so ubiquitous that a search for the phrase "discovery dispute" in a federal district court database for a twelve-month period yields over

2. "Document discovery" refers to discovery of both electronic and paper documents.

3. See Dan H. Willoughby, Jr. et al., Sanctions for E-Discovery Violations: By the Numbers, 60 DuKE L.J. 789 (2010). See generally infra Part I. Though Part I does not attempt to quantify the problem, it cites numerous cases in which attorneys have violated procedural rules, court orders, and common law duties. It also looks at the rising number of sanctions used to address discovery misconduct, which has been quantified recently.

4. Infra Part I. 
fourteen hundred cases. ${ }^{5}$ Federal judges are understandably frustrated by attorneys' failure to comply with the law and with their constant need for court intervention. ${ }^{6}$ U.S. Magistrate Judge Paul W. Grimm once lamented, "[C]ounsel for both Plaintiff and Defendant have exhibited a disturbing lack of knowledge of, or disregard for, the Federal Rules of Civil Procedure .... The discovery violations by both attorneys are numerous and vividly demonstrate how discovery should not be practiced."7

A representative example of attorney document discovery misconduct is provided by the case 1100 West, LLC v. Red Spot Paint \& Varnish Co. ${ }^{8}$ Attorneys practicing in the law firm Bose McKinney \& Evans, LLC (BME) represented Red Spot in litigation (filed in 2005) in which the key issue was whether the chemicals TCE and PCE, which may present health risks at certain levels of exposure, had been used on Red Spot property. ${ }^{9}$ On the eve of trial in 2008, the plaintiff, 1100 West, made a Freedom of Information Act (FOIA) request to the Environmental Protection Agency (EPA) to obtain certified copies of documents. ${ }^{10}$ The EPA file contained documents Red Spot had not previously produced in discovery (even though they were responsive to requests for production), including documents reflecting the presence of TCE on Red Spot property. ${ }^{11} 1100$ West filed a motion for an emergency hearing on October 14 , 2008. ${ }^{12}$ Thereafter, BME attorneys produced the EPA documents, characterizing the delayed production as an unintentional oversight. ${ }^{13}$

After 1100 West filed a motion for sanctions on October 27, 2008, and sought additional discovery regarding the alleged discovery misconduct, the court

5. Admittedly, the search is over-inclusive (the existence of a discovery dispute does not always indicate misconduct in document discovery), and under-inclusive (not every violation of a discovery obligation is brought to a court's attention or characterized as a "discovery dispute"). Nonetheless, this search provides a sense of how often federal district courts address allegations of discovery conduct that violates legal obligations. See also infra note 162.

6. See, e.g., Marti v. Baires, No. 1:08-cv-00653-AWI-SKO PC, 2012 WL 2029720, at*5 (E.D. Cal. June 5, 2012) ("[T]he Court is now embroiled in the minutiae of the parties' discovery disputes . . ."); Atlas Res., Inc. v. Liberty Mut. Ins. Co., 297 F.R.D. 482, 492 (D.N.M. 2011) (describing counsel's "cavalier, often disdainful, attitude" toward discovery); Adelman v. Boy Scouts of Am., 276 F.R.D. 681, 684 (S.D. Fla. 2011) (describing attorney objections that were not "even remotely supported by the law governing discovery" and the "mini-litigation" necessitated by those objections).

7. Mezu v. Morgan State Univ., 269 F.R.D. 565, 570-71 (D. Md. 2010).

8. No. 1:05-cv-1670-LJM-JMS, 2009 WL 1605118 (S.D. Ind. June 5, 2009).

9. $I d$. at $* 1, * 3$.

10. See id. at *5. Ironically, the FOIA request was necessary because BME attorneys refused to certify the authenticity of the documents. See id.

11. Id. 1100 West learned that BME had received a copy of the EPA file in August 2007. Id. Later in discovery, BME confirmed that some of the documents had been contained in Red Spot files that had not previously been reviewed and produced. $I d$. at *24 (noting that some of the EPA documents were in the boxes and file cabinets that Red Spot did not review and produce in discovery).

12. Id. at $* 5$.

13. Id. at *6-9. 
advised Red Spot to obtain separate counsel. ${ }^{14}$ In December 2008, Red Spot's new attorneys produced 70,000 responsive documents from sixty-eight boxes and two filing cabinets, including numerous documents reflecting the use of PCE and TCE on the property. ${ }^{15}$ Discovery concerning the discovery misconduct revealed that in May 2006, BME attorneys had concerns about the completeness of their document production, with one attorney characterizing the issue as "a little bit scary" and another suggesting, "I think someone needs to go hold [the client's] hand for a day for a comprehensive file search ...."16 Nonetheless, in June 2006, when a BME attorney was given access to the client's documents, the attorney apparently did not conduct a search for responsive documents or guide the client in conducting such a search. ${ }^{17}$ BME later conceded its attorneys had failed to produce responsive documents. ${ }^{18}$

In this and numerous other cases of discovery misconduct, federal courts must decide which consequences should be imposed to punish and deter future misconduct. Federal judges have increasingly turned to sanctions, ${ }^{19}$ but not professional discipline. ${ }^{20}$

That was the case in 1100 West. After reviewing the discovery misconduct in the case, the court entered a default judgment against Red Spot and ordered Red Spot and BME to each pay half of 1100 West's attorneys' fees and costs for discovery during a three-year period. ${ }^{21}$ The court detailed Red Spot's efforts to hide its use of TCE and PCE and then turned to the role played by BME attorneys, stating "BME [attorneys] had opportunities to steer Red Spot ... on a different path and [they] never did." 22 The court explained that the attorneys knew enough information by June 2006 that they should have guided their client to make complete disclosure in discovery. ${ }^{23}$ Noting the BME attorneys' questions

\footnotetext{
14. Id. at $* 9$.

15. Id. at *10-11. In February and April 2009, Red Spot produced additional responsive documents. Id. at $* 11, * 19$.

16. Id. at *22-23. The court allowed discovery of attorney-client privileged communications upon determining Red Spot had waived the privilege through discovery fraud. Id. at *10. Also during this time period, BME attorneys were aware that some Red Spot witnesses had recollections regarding the use of TCE and PCE but that Red Spot's 30(b)(6) designee did not provide this information in her deposition and Red Spot's interrogatory answers did not reference that information. Id. at *11-19.

17. See id. at $* 23$.

18. $I d$. at *1. The firm argued that it should not be sanctioned because it had relied upon its client and "once the firm knew of the potential misconduct [by two firm attorneys], it promptly took steps [to] remove those lawyers from the firm and cooperated fully with 1100 West." Id.

19. Willoughby et al., supra note 3, at 790-91 (describing the significant increase in ediscovery-related motions for sanctions and awards since 2004); Douglas R. RichMOND ET AL., ProfESSIONAL ReSPONSIBILITY IN LitigATION 416 (2d ed. 2016) (noting the "plentiful" sanctions rulings in the ediscovery era); see also infra notes 99-102 and accompanying text.

20. See infra Part III.

21. 1100 W., 2009 WL 1605118 , at *35. The order also required Red Spot and BME to pay attorneys' fees and costs associated with certain other motions and hearings. $I d$.

22. $I d$. at $* 32$.

23. See id. at $* 33$.
} 
about the completeness of the document production and their physical visit to the room where the responsive documents were located, the court concluded that BME had an obligation to "insist that Red Spot dig deeper." 24 The court acknowledged it is rare to hold a law firm accountable for violating the FRCP, but determined it was necessary to deter future misconduct. ${ }^{25}$

The attorneys in the 1100 West case did not face professional discipline for their egregious discovery misconduct. ${ }^{26}$ Most attorneys who engage in document discovery misconduct do not. ${ }^{27}$ This is the case even though professional conduct rules prohibit every aspect of discovery abuse, from failure to produce requested documents to spoliation of evidence. ${ }^{28}$ Further, most federal courts have their own disciplinary systems, ${ }^{29}$ and judges and lawyers alike have an ethical obligation to report attorney misconduct. ${ }^{30}$ Though the tools are in place, the discipline system is not being used to address pervasive discovery misconduct. ${ }^{31}$

This Article argues that federal courts could make more effective use of attorney discipline systems to improve document discovery in civil cases. What will be effective depends on why discovery misconduct occurs. There are multiple reasons why lawyers may engage in such misconduct-from ignorance of the rules to intentional, calculated violation of the law. The best explanation for most discovery misconduct, though, is that lawyers do not think they are doing anything wrong.

Behavioral legal ethics explains how cognitive bias, situational pressures, and other factors influence attorney behavior in discovery. This Article makes the case that federal judges could counteract these factors-and perhaps even harness the power of behavioral science-by consistently educating attorneys about discovery expectations and consistently imposing disciplinary consequences for discovery misconduct. These changes could fundamentally change the way lawyers conduct discovery. While some may argue that consistent imposition of sanctions could have the same impact, the Article presents the reasons attorney discipline is superior to sanctions alone.

Following this Introduction, Part I describes common areas of attorney misconduct in document discovery in civil litigation in federal court. This discussion explains the governing procedural rules and other law and provides examples of how attorneys regularly violate their legal obligations in each area.

\footnotetext{
24. Id. at $* 34$

25. $I d$. at $* 35$. The sanction was not entered against the individual attorneys. Id.

26. Research for discipline records included a Westlaw search in both the Northern District of Indiana and Indiana state court, as well as a search for discipline records in the online database, "Indiana Roll of Attorneys." 27. See infra Part III.

28. See Model Rules of Prof'L Conduct R. 3.4(a), 3.4(c)-(d) (2016) [hereinafter Model Rules]; see also discussion infra notes 103-14 and accompanying text.

29. See infra notes 118-19 and accompanying text.

30. See infra note 114 and accompanying text.

31. See infra Part III.
} 
This Part concludes by discussing the availability of sanctions and the rise in their use in recent years. With that foundation, Part II explains the professional conduct rules pertinent to document discovery practice and the discipline systems that could be used to address misconduct. Thereafter, Part III considers the dearth of document discovery-related disciplinary proceedings originating from misconduct in federal court. A contributing factor to the lack of discipline appears to be the low number of disciplinary referrals. Part IV discusses the reasons attorneys do not report the discovery misconduct of opposing counsel and the somewhat different reasons judges do not make discipline referrals.

With this understanding of the lack of discipline and some of the reasons for it, Part $\mathrm{V}$ argues for reform, explaining the appropriate cases for discipline referrals, how behavioral legal ethics research should influence judges to consistently turn to the discipline system, and the advantages of discipline over sanctions alone. Then, Part VI discusses three different settings in which discovery discipline reform could be achieved: at the judge-level, court-level, and nationally. This Part considers specific ideas for implementing change in each setting and the reasons some of these avenues may be more effective than others.

\section{Attorney Misconduct in Federal Civil Document Discovery Practice and the Availability and Use of Sanctions to Combat It}

The basic framework of discovery in a civil case in federal court has been the same since the adoption of the FRCP in $1938 .^{32}$ A party may request that an opponent produce documents within the scope of discovery, which generally encompasses documents that are nonprivileged, relevant, and (as more recently delineated) proportional to the needs of the case. ${ }^{33} \mathrm{~A}$ party to whom a request is made then has the opportunity to object to any improper requests for production, review its own documents to determine which are responsive to the request (but not objectionable), and produce those non-objectionable documents. ${ }^{34}$ The default rule is that the responding party pays the costs associated with responding to a discovery request. ${ }^{35}$

When a responding party does not produce documents that the requesting party believes it is entitled to receive, the requesting party can file a motion to

32. See generally Milberg LLP \& Hausfeld LLP, E-Discovery Today: The Fault Lies Not in Our Rules . . , 4 FED. CTS. L. REv. 131, 137-44 (2011) (explaining the role of discovery in federal court since the rules were adopted in 1938).

33. FED. R. Civ. P. 26(b)(1), 34; see also infra notes 48-49.

34. Fed. R. Civ. P. 34.

35. See Oppenheimer Fund Inc. v. Sanders, 437 U.S. 340, 358 (1978) (explaining that the responding party ordinarily bears the cost). 
compel. ${ }^{36}$ Though filed by the requesting party, a motion to compel is a vehicle for both parties to argue about the impropriety of the opponent's conduct. The requesting party will assert that it is entitled to withheld documents and that any objections to their production are not justified, ${ }^{37}$ while the responding party will argue that an opponent's requests seek documents beyond the scope of discovery or documents otherwise protected from discovery. ${ }^{38}$ Either a requesting or responding party (and the party's attorney) can be sanctioned for failing to comply with their discovery obligations. ${ }^{39}$

In the 1990s, the advent of email and desktop computers resulted in an explosion of electronic documents. ${ }^{40}$ The new volume of information was a discovery game changer in terms of cost, complexity, and number of discovery disputes. $^{41}$ The 2006 amendments to the FRCP clarified that an electronic document is a document to which the ordinary rules of discovery apply. ${ }^{42}$ The 2015 amendments attempted to address some problems that had intensified in the ediscovery era, but did not alter the basic framework for discovery. ${ }^{43}$

The following discussion considers common areas of attorney misconduct in document discovery practice. Each section describes the applicable FRCP provisions and other sources of authority and numerous examples of how attorneys frequently run afoul of this authority. This Part concludes with a discussion of the availability of sanctions for noncompliance with the discovery rules and the rise in the imposition of sanctions in recent years. This survey of the landscape is foundational for considering the issue addressed in the remainder of this Article: in what circumstances should attorneys face professional discipline for their role in document discovery misconduct?

36. Fed. R. Civ. P. 37(a)(3)(B). Alternatively, the party from whom discovery is requested could seek a protective order, which in this context would be a ruling that the requesting party is not entitled to receive the requested discovery. See FED. R. CIV. P. 26(c).

37. See Fed. R. Civ. P. 37(a)(3)-(4).

38. See FED. R. Civ. P. 37(a)(5)(B) ("If a motion [to compel] is denied, the court may issue any protective order authorized [by FRCP 26(c)] ....").

39. Sanctions may be entered under the authority of the FRCP, a court's inherent power, or statutory authority. See generally 28 U.S.C. § 1927 (2012) (stating that attorney who "so multiplies the proceedings ... unreasonably and vexatiously" can be required to pay excess costs, expenses, and attorneys' fees); FED. R. CIV. P. 26(c), 26(g), 37(a)-(b); Chambers v. NASCO, Inc., 501 U.S. 32, 44-45 (1991) (courts have inherent authority to "fashion an appropriate sanction for conduct which abuses the judicial process").

40. Damian Vargas, Note and Comment, Electronic Discovery: 2006 Amendments to the Federal Rules of Civil Procedure, 34 Rutgers Computer \& TeCH. L.J. 396, 397 (2008) (explaining that the proliferation of computers and email resulted in an explosion of electronic information).

41. Willoughby et al., supra note 3, at 792 (describing document discovery in the ediscovery era as "more expensive, more complicated, and more contentious than ever").

42. FED. R. CIV. P. 34(a) (describing party's right to request "documents or electronically stored information"); see also Vargas, supra note 40, at 408-14 (describing 2006 amendments to the FRCP).

43. See generally Reports of the Committee on Rules of Practice and Procedure to the Judicial Conference of the United States accompanying Letters from Honorable John G. Roberts to the Honorable John A. Boehner and Honorable Joseph R. Biden, Jr. (Apr. 29, 2015) (submitting to Congress 2015 amendments to the FRCP). 


\section{A. OVERBROAD REQUESTS FOR PRODUCTION OF DOCUMENTS}

One area of discovery conflict—and potential attorney misconduct—concerns parties making overbroad document requests. In a system in which the producing party pays the cost of complying with an opponent's discovery requests, the breadth of discovery requests can have a significant impact on the cost of a case. ${ }^{44}$ This problem is amplified in the ediscovery era when humans seldom have a thought that is not recorded in an electronic document. When all of those emails, texts, instant messages, and voicemails are relevant or potentially relevant to an issue in a case, costs of production can be high. ${ }^{45}$

Historically, courts and counsel viewed the scope of discovery as broad. Parties generally had the right to seek discovery of all nonprivileged information relevant to a claim or defense. ${ }^{46}$ But there are two key limits on a party's entitlement to all nonprivileged information relevant to a claim. The first is proportionality. Though concepts of proportionality have been incorporated in the FRCP since $1983,{ }^{47}$ it was not until 2015 that the rules were rewritten to limit the scope of discovery to information that is both relevant and proportional to the needs of the case. ${ }^{48}$ The goal of these amendments is for parties and ultimately courts to rein in the reach (and cost) of discovery. ${ }^{49}$ By incorporating proportionality into the text of the scope rule, the hope is that judges will no longer revert to the mantra that requested documents should be produced because parties have a

\footnotetext{
44. See Jacqueline Hoelting, Note, Skin in the Game: Litigation Incentives Changing as Courts Embrace a “Loser Pays” Rule for E-Discovery Costs, 60 CLEv. ST. L. REv. 1103, 1114 (2013) (asserting that "[p]laintiffs have taken advantage of [the rule that the producing party pays] by submitting overly broad and expensive requests" for production).

45. Id. at 1112-13.

46. Fed. R. Civ. P. 26(b)(1) (2014) (amended 2015). Prior to 2015, Rule 26(b)(1) further reinforced this idea of broad discovery by explaining that a document request is not objectionable because it seeks documents inadmissible in evidence, so long as the request is "reasonably calculated to lead to the discovery of admissible evidence." Id.

47. Jennifer Nicholls, Comment, A Proportional Response: Amending the Oregon Rules of Civil Procedure to Minimize Abusive Discovery Practices, 89 OR. L. REv. 1445, 1452-56 (2011) (tracing the origin and evolution of references to proportionality in the FRCP).

48. FED. R. CIV. P. 26(b)(1) ("Parties may obtain discovery regarding any nonprivileged matter that is relevant to any party's claim or defense and proportional to the needs of the case, considering the importance of the issues at stake in the action, the amount in controversy, the parties' relative access to relevant information, the parties' resources, the importance of discovery in resolving the issues, and whether the burden or expense of the proposed discovery outweighs its likely benefit."). A corresponding change was made to Rule 26(b)(2)(C)(iii) (where the proportionality language was previously located) to state that a court must limit discovery if it determines that "the proposed discovery is outside the scope permitted by Rule 26(b)(1)." FED. R. CIV. P. 26(b)(2)(C)(iii).

49. Fed. R. Civ. P. 26 advisory committee's note to 2015 amendment ("The present [proportionality] amendment again reflects the need for continuing and close judicial involvement in the cases that do not yield readily to the ideal of effective party management.").
} 
right to broad discovery, ${ }^{50}$ but will instead engage in analysis of the benefits and burdens associated with a party's request for production, limiting requests as appropriate under that standard. ${ }^{51}$

The second limit is the discovery certification requirement found in FRCP $26(\mathrm{~g}){ }^{52}$ The rule requires counsel seeking discovery to certify that the request is not made for an improper purpose ${ }^{53}$ and that the request is "neither unreasonable nor unduly burdensome or expensive." ${ }^{54}$ This rule has been described as "aspir[ing] to eliminate one of the most prevalent of all discovery abuses: kneejerk discovery requests served without consideration of cost or burden to the responding party." ${ }^{, 5}$

While some requests for production are clearly overbroad, ${ }^{56}$ in many cases it can be difficult to know the line between proportional and improper discovery requests. Because a responding attorney can object to discovery that it believes crosses the line and not produce documents unless ordered to do so by a court, ${ }^{57} \mathrm{a}$ proactive attorney and court can control the costs of overbroad discovery. ${ }^{58}$

\section{B. A LACK OF TRANSPARENCY REGARDING THE SPECIFIC BASIS FOR OBJECTIONS AND CONCERNING DOCUMENTS PRODUCED OR WITHHELD}

Perhaps the most difficult aspect of document discovery is the necessary dependence upon opposing counsel to respond to requests for production. Typically, a party responding to a document request does not open up its files and allow the requesting attorney to determine which documents are responsive to its

50. See, e.g., Convertino v. U.S. Dep't of Justice, 565 F. Supp. 2d 10, 12 (D.D.C. 2008) (“The scope of discovery in civil actions is broad, allowing for discovery regarding any nonprivileged matter that is relevant to a claim or defense.").

51. See generally Kroll Ontrack, 6 Months of Case LaW Under the New FRCP 7 (2016) (ebook), http://www.ediscovery.com/cms/pdf/caselawfrcp_ebook_krollontrack2016.pdf [https://perma.cc/9ANTBNY6] (explaining the amendment is intended to encourage judges to play a more active role, to consider proportionality up front and not tolerate broad discovery requests). But see Wit v. United Behavioral Health, No. 14-cv-02346-JCS, 2016 WL 258604, at*10 (N.D. Cal. Jan. 21, 2016) ("Traditionally, the relevance requirement of Rule 26(b)(1) has been construed broadly.").

52. FED. R. CIV. P. 26(g).

53. FED. R. CIV. P. 26(g)(1)(B)(ii) (defining improper purpose as including a purpose "such as to harass, cause unnecessary delay, or needlessly increase the cost of litigation").

54. FED. R. CIV. P. 26(g)(1)(B)(iii) (factors listed in the rule as relevant to this determination are "the needs of the case, prior discovery in the case, the amount in controversy, and the importance of the issues at stake in the action").

55. Mancia v. Mayflower Textile Servs. Co., 253 F.R.D. 354, 358 (D. Md. 2008).

56. See, e.g., Edelen v. Campbell Soup Co., No. 1:08-cv-00299-JOF-LTW, 2009 WL 4798117, at *2 (N.D. Ga. Dec. 8, 2009) (describing a "blanket request" for all information on laptops of numerous company executives as "on its face overbroad").

57. See Fed. R. Civ. P. 34, 37; see also 8A Charles A. Wright et al., Federal Practice and Procedure $\S 2207$, at 386-87 (2d ed. 1994) ("If the request is objected to, it is for the discovering party to decide whether to pursue the matter further.").

58. See, e.g., Witt v. GC Servs. Ltd. P'ship, 307 F.R.D. 554, 569 (D. Colo. 2014) ("I am loath to require additional answers to unfocused or broadly drafted ... requests for production."). 
requests. ${ }^{59}$ Instead, the requesting party must rely upon the responding party's attorney to fairly interpret the requests, to transparently describe legitimate, specific objections relied upon in withholding any documents from the production, and to diligently identify and produce documents that are responsive (i.e., requested and not objectionable) to the requests. ${ }^{60}$ There is not a "nonresponsive" log where the responding attorney describes the documents it has withheld (or not searched for) based on its objections, so there is no simple way for the requesting party to identify an adversary's decision not to produce a valuable document. ${ }^{61}$

Without transparency, the requesting party cannot know if it should be troubled by and challenge the decisions or conduct of opposing counsel. To that end, the 2015 amendments to the FRCP clarify that objections must be stated "with specificity" 62 and that "[a]n objection must state whether any responsive materials are being withheld on the basis of that objection." ${ }^{63}$ But even before those amendments, non-specific objections were inconsistent with the requirements of Rule $34 .{ }^{64}$ Further, FRCP $26(\mathrm{~g})$ requires an attorney to certify that to the best of his or her "knowledge, information, and belief formed after a reasonable inquiry" the discovery responses and objections are consistent with the rules and applicable law and are "not interposed for any improper purpose, such as to harass, cause unnecessary delay, or needlessly increase the cost of litigation." U.S. Magistrate Judge Paul W. Grimm has discussed that the purpose of this certification is to address the abusive practice of "objecting to discovery requests reflexively—but not reflectively—and without a factual basis."

59. The rules reference producing documents for inspection or copying by an opponent. FED. R. Civ. P. 34(a)(1). In practice, parties generally copy documents and produce those copies to the opponent. The 2015 amendments specifically reference this practice. See FED. R. CIV. P. 34(b)(2)(B) ("The responding party may state that it will produce copies of documents or of electronically stored information instead of permitting inspection.").

60. See Witt, 307 F.R.D. at 561 (explaining that the responding party must object "with specificity," "explain and support its objections," and "[m]ost importantly... answer to the extent a discovery request is not objectionable").

61. $C f$. FED. R. CIv. P. 26(b)(5)(A) (requiring attorneys to create a privilege log, describing documents withheld on the basis of privilege or work product protection).

62. FED. R. CIV. P. 34(b)(2)(B).

63. FED. R. CIv. P. 34(b)(2)(C); see also id. advisory committee's note to 2015 amendment ("An objection that states the limits that have controlled the search for responsive and relevant materials qualifies as a statement that the materials have been 'withheld."').

64. FED. R. Civ. P. 34(b)(2)(B)-(C) (2014) (amended 2015); see also Panola Land Buyers Ass'n v. Shuman, 762 F.2d 1550, 1559 (11th Cir. 1985) (explaining that discovery objections must be "plain enough and specific enough so that the court can understand in what way the [discovery is] alleged to be objectionable" (quoting Davis v. Fendler, 650 F.2d 1154, 1160 (9th Cir. 1981)); PLX, Inc. v. Prosystems, Inc., 220 F.R.D. 291, 293 (N.D.W. Va. 2004) ("The mere recitation of the familiar litany that [a] ... document production request is overly broad, burdensome, oppressive and irrelevant will not suffice." (quoting Momath v. Albert Einstein Med. Ctr., 164 F.R.D. 412, 417 (E.D. Pa. 1996)) (internal quotation marks omitted)).

65. Fed. R. Civ. P. 26(g).

66. Mancia v. Mayflower Textile Servs. Co., 253 F.R.D. 354, 358 (D. Md. 2008). 
A boilerplate (or non-specific) objection ${ }^{67}$ might provide: "[Party] objects to the extent this request seeks irrelevant documents and to the extent the request is overly broad and unduly burdensome. Subject to and without waiving these objections, responsive, non-objectionable documents, if any, will be produced."68 Such objections may be asserted in a "general objection" section or used in response to several (or all) of an opponent's requests for production. ${ }^{69}$ When attorneys make objections like this, opposing counsel does not know if any responsive material is actually being withheld on the basis of the objection, and if so, how decisions about what to withhold and what to produce were made. ${ }^{70}$

As a result of boilerplate objections, one of two bad scenarios may occur, ${ }^{71}$ though the second is substantially worse than the first. In the first scenario, the attorney who receives the boilerplate objections spends time and money filing a motion to compel to seek any documents withheld based on the objections. ${ }^{72}$ In turn, this creates a burden for the court system and ultimately an order resolving the issue (typically finding the objections waived and ordering any documents withheld on that basis produced). ${ }^{73}$ In the second scenario, the objecting attorney (in his or her mind, but not on paper) justified withholding responsive documents based on the vague, boilerplate objections, but the requesting attorney does not

67. Matthew L. Jarvey, Note, Boilerplate Discovery Objections: How They Are Used, Why They Are Wrong, and What We Can Do About Them, 61 DraKe L. Rev. 913, 914 (2013) (describing a boilerplate objection as one that does not specify "how the discovery request is deficient" or "how the objecting party would be harmed if it were forced to respond").

68. Id. at $914-15$ (noting boilerplate objections include that a request is "irrelevant" or "overly broad" without including an explanation why).

69. See, e.g., id. at 915 (explaining that boilerplate objections are often "used repetitively, in response to several requests”). But see, e.g., Swackhammer v. Sprint Corp. PCS, 225 F.R.D. 658, 660-61 (D. Kan. 2004) ("This Court has ... disapproved of the practice of asserting a general objection 'to the extent' it may apply to particular requests for discovery. [Such an objection is] worthless for anything beyond delay of the discovery.").

70. Weems v. Hodnett, No. 10-cv-1452, 2011 WL 3100554, at *1 (W.D. La. July 25, 2011) (explaining that boilerplate objections "waste [the] time [of] opposing counsel and the court [because] it is impossible to know whether information has been withheld and, if so, why").

71. A third—and not bad-result is that the requesting party does not challenge the boilerplate objections and the objecting attorney was not actually withholding any documents based on those objections. Undoubtedly, this occurs in countless cases. The problem is that the requesting party has no way of knowing if her choice not to file a motion to compel was a good one (because no documents were withheld) or a bad one (because documents were withheld based on the objections).

72. See, e.g., Atlas Res. Inc. v. Liberty Mut. Ins. Co., 297 F.R.D. 482, 489-90 (D.N.M. 2011) (ruling that Liberty's blanket objections were improper, that the objections were waived, and that any documents withheld on the basis of objections must be produced); Sunnen Prods. Co. v. Travelers Cas. \& Sur. Co. of Am., No. 4:09CV00889 JCH, 2010 WL 743633, at*1 (E.D. Mo. Feb. 25, 2010) (court overruled all boilerplate objections in ruling on motion to compel); Frontier-Kemper Constructors, Inc. v. Elk Run Coal Co., 246 F.R.D. 522, 527-28 (S.D.W. Va. 2007) (finding defendant did not comply with FRCP 34 and thereby waived its generic and nonspecific objections to requests for production); DL v. District of Columbia, 251 F.R.D. 38, 43 (D.D.C. 2008) (explaining that defendant's boilerplate general objections provide "no indication as to the specific nature or amount of material being withheld on the basis of the general objections"); Heller v. City of Dallas, 303 F.R.D. 466, 495 (N.D. Tex. 2014) (ordering the City of Dallas to provide every attorney that represents it in federal court a copy of the order explaining why the City's boilerplate objections are improper).

73. Supra note 72. 
realize documents are being withheld, does not pursue a motion to compel, and is prejudiced by never (or only belatedly) receiving the documents deceptively withheld. ${ }^{74}$ In both of these scenarios, the requesting party is harmed by the lack of transparency that is part and parcel of non-specific objections. ${ }^{75}$

In terms of the document production itself, a requesting party usually has no choice but to assume that the responding attorney (and party) exercised care and diligence in identifying and producing responsive documents. ${ }^{76}$ Problems occur when responding attorneys and their clients intentionally withhold responsive documents or act negligently in identifying and producing responsive documents. ${ }^{77}$ The requesting party will be prejudiced by the non-production or delay

74. See, e.g., Qualcomm, Inc. v. Broadcom Corp., No. 05cv1958-B (BLM), 2008 WL 66932, at*8 (S.D. Cal. Jan. 7, 2008) (objections and responses to request for production appeared to signal that requested documents would be produced, thus, no motion to compel was filed; however, attorneys interpreted their objections and responses as justifying nonproduction of documents). The hazards of a lack of transparency in objections is highlighted by the attorney's explanation of how he interpreted his own objections in justifying non-production of key documents in the case:

With respect to Request for Production No. 50, Qualcomm viewed that request as overbroad. The only standard relevant to this case was the H.264 standard for video compression (also known as the ISO/IEC MPEG-4 Part 10 standard, as explained above). The two patents-in-suit, however, claim technologies beyond the specific video compression technology that was at issue in this case. I was aware that there could be standards beyond H.264 that related to the processing of video signals and to the two patents-in-suit, potentially including standards created by the same standards-setting organization that created the H.264 standard. For that reason, the responses include objections on grounds of relevance, and express Qualcomm's commitment to produce documents given to or received from the standards-setting organization that created the H.264 standard, and that concerned Qualcomm's involvement in setting that standard. I believed in good faith that this response limited Qualcomm's production commitment to include all documents that were both responsive to the request and relevant to the case. I also believed that the response made it clear to counsel for Broadcom what counsel for Qualcomm believed was relevant and would be produced.

Declaration of Non-party Christian E. Mammen in Response to Order to Show Cause Why Sanctions Should Not Be Imposed at II 27(c), Qualcomm, Inc. v. Broadcom Corp., 2007 WL 3005523 (S.D. Cal. 2007) (No. 05CV1958-B (BLM)); see also infra note 129 for subsequent history in the Qualcomm case.

75. While some attorneys make these objections to deceive, many others do it out of habit or because they think it is necessary to preserve objections. See Anderson v. Caldwell Cty. Sheriff's Office, No. 1:09cv423, 2011 WL 2414140, at $* 3$ (W.D.N.C. June 10, 2011) (explaining that the FRCP does not allow parties to make objections for the purpose of preserving them). Regardless of the motive, all attorneys who make boilerplate objections are not being transparent about what they are doing and why, and as a result, they are creating a problem.

76. FED. R. CIV. P. 34 (responding party has duty to produce documents requested if no objection is made). Unless the responding party asserts an objection or otherwise gives opposing counsel specific reason for concern that a document production is incomplete, there is no basis for filing a motion to compel.

77. See, e.g., Sun River Energy, Inc. v. Nelson, 800 F.3d 1219, 1223 (10th Cir. 2015) (counsel did not produce relevant insurance policy because attorney did not review the policy to determine its relevance); Witt v. GC Servs. Ltd. P'ship, 307 F.R.D. 554, 568-69 (D. Colo. 2014) (explaining that attorney has an obligation to "conduct a reasonable search for responsive information" and that defense counsel failed to produce responsive documents, and imposing \$500 sanction for violating FRCP 26(g)); 1100 W., LLC v. Red Spot Paint \& Varnish Co., No. 1:05-cv-1670-LJM-JMS, 2009 WL 1605118, at *11, *33 (S.D. Ind. June 5, 2009) (defendant belatedly produced thousands of responsive documents related to the key issue in the case, and facts revealed that attorneys had concerns about completeness of document production but did not index or review sixty-eight 
in production as it conducts other discovery and prepares for trial without knowing the information is missing. ${ }^{78}$

\section{NEGLIGENT OR INTENTIONAL SPOLIATION OF EVIDENCE}

As a matter of common law, when a party reasonably anticipates litigation, the party has an obligation to preserve documents discoverable by an opponent in that litigation. ${ }^{79}$ Failure to fulfill this duty (whether through intentional or negligent conduct) is termed spoliation. ${ }^{80}$

The information age has complicated issues of preservation. In modern litigation, preservation is no longer as simple as counsel taking custody of a client's folder or box of documents related to the contract, real estate venture, or fired employee. Instead, an attorney must issue, provide guidance regarding, and monitor a litigation hold - a directive to a party to litigation (and its employees if applicable) that the party must preserve and not delete or destroy discoverable information. ${ }^{81}$ The relatively easy part for an attorney should be issuing a written litigation hold to a client (and for an entity client, its key players) to preserve discoverable information. ${ }^{82}$ The more difficult part of preservation is working with the client to identify discoverable information in its various locations so that it can be collected and preserved. ${ }^{83}$

boxes and two filing cabinets of documents in defendant's possession); R \& R Sails Inc. v. Ins. Co. of Pa., 251 F.R.D. 520, 524-25 (S.D. Cal. 2008) (determining that defendant's counsel did not make a reasonable inquiry into whether it had documents responsive to plaintiff's requests for production); Poole ex rel. Elliott v. Textron, Inc., 192 F.R.D. 494, 505 (D. Md. 2000) (explaining the initial search was inadequate as evidenced by documents produced following a court order).

78. Sun River, 800 F.3d at 1222 (coverage had lapsed under insurance policy by the time it was belatedly produced); Atlas Res. Inc. v. Liberty Mut. Ins. Co., 297 F.R.D. 482, 490 (D.N.M. 2011) (plaintiff learned in deposition that documents a witness had turned over to the defendant, and that defendant had been ordered to produce, were not produced to plaintiff); $1100 \mathrm{~W}$., $2009 \mathrm{WL} 1605118$, at $* 35$ (as sanction for belated production of thousands of responsive documents and other discovery misconduct, court sanctioned defendant and its lawyers to pay attorneys' fees and costs for discovery from May 23, 2006 to June 5, 2009); Poole, 192 F.R.D. at 507 ("[T]here is an unquantifiable but real prejudice to plaintiff in the motions practice that Textron's conduct necessitated and the ... disadvantages of the delayed . . . discovery that was its consequence.").

79. Fujitsu Ltd. v. Fed. Express Corp., 247 F.3d 423, 436 (2d Cir. 2001).

80. Graff v. Baja Marine Corp., 310 F. App'x 298, 301 (11th Cir. 2009) (defining spoliation as the "destruction or significant alteration of evidence, or the failure to preserve property for another's use as evidence in pending or reasonably anticipated litigation" (quoting West v. Goodyear Tire \& Rubber Co., 167 F.3d 776, 779 (2d. Cir. 1999)).

81. Zubulake v. UBS Warburg LLC, 220 F.R.D. 212, 218 (S.D.N.Y. 2003) (“Once a party reasonably anticipates litigation, it must suspend its routine document retention/destruction policy and put in place a 'litigation hold' to ensure the preservation of relevant documents.").

82. Even though this should be the easy part, attorneys sometimes fail to issue litigation holds or fail to communicate the hold to the appropriate people. See, e.g., Knickerbocker v. Corinthian Colls., 298 F.R.D. 670, 674 (W.D. Wash. 2014) (counsel for defendant did not issue a company-wide litigation hold, resulting in email accounts being deleted).

83. Nacco Materials Handling Grp., Inc. v. Lilly Co., 278 F.R.D. 395, 398, 404 (W.D. Tenn. 2011) (counsel issued written litigation hold to client's president, but did nothing to ensure that discoverable information was identified and preserved); Bd. of Regents of the Univ. of Neb. v. BASF Corp., No. 4:04CV3356, 2007 WL 
Without a proper effort by both attorney and client to identify and preserve discoverable information, information can be lost. It may be deleted through some automatic computer process. ${ }^{84}$ Or information may be deleted intentionally - by a client who does not understand the legal obligation to preserve it and the consequences of failing to do so (or who is willing to take the chance). ${ }^{85}$

Traditionally, courts relied upon inherent authority to sanction spoliation, ${ }^{86}$ which resulted in varying approaches to the severity of sanctions imposed for non-intentional spoliation. ${ }^{87}$ In 2015, FRCP 37(e) was amended ${ }^{88}$ to make severe sanctions (like adverse inference instructions, default, and dismissal) available only for intentional spoliation. ${ }^{89}$ Less severe sanctions are available when a party is prejudiced by an opposing party's non-intentional spoliation of evidence. ${ }^{90}$ The rule does not contain a provision addressing sanctions against an attorney for spoliation. $^{91}$

3342423, at *4 (D. Neb. Nov. 5, 2007) (attorney requested "documents" from key employee of plaintiff, who did not understand the request to encompass electronic information, resulting in information being deleted and belatedly collected).

84. See, e.g., Knickerbocker, 298 F.R.D. at 674 (explaining that the process to automatically delete terminated employees' email accounts should have been suspended in light of EEOC notices, but was not, resulting in deletion of accounts); Nacco, 278 F.R.D. at 405 (finding it probable that relevant ESI such as Internet history and server logs were lost by defendant's failure to copy data on its server or preserve backup tapes at the time its preservation duty attached); Bd. of Regents of the Univ. of Neb., 2007 WL 3342423, at *4 (explaining that the University's computer system deleted some emails automatically if not preserved).

85. Bd. of Regents of the Univ. of Neb., 2007 WL 3342423, at *4 \& n.2 (key employee of plaintiff was not told that he should preserve ESI, so he preserved only "what he deemed was important" and "deleted what he viewed as unimportant”); HM Elecs., Inc. v. R.F. Techs., Inc., No. 12CV2884-BAS-MDD, 2015 WL 4714908, at *1 (S.D. Cal. Aug. 7, 2015), vacated in part, No. 12-CV-2884-BAS-MDD, 2016 WL 1267385 (S.D. Cal. Mar. 15,2016 ) (defendant's CEO instructed employees to destroy documents relevant to the suit and attorneys did not implement a litigation hold or communicate the importance of preserving documents).

86. Hodge v. Wal-Mart Stores, Inc., 360 F.3d 446, 449 (4th Cir. 2004).

87. Pension Comm. of Univ. of Montreal Pension Plan v. Banc of Am. Sec., LLC, 685 F. Supp. 2d 456, 478 (S.D.N.Y. 2010) (adverse inference instruction appropriate for spoliation caused by gross negligence of party); Rimkus Consulting Grp., Inc. v. Cammarata, 688 F. Supp. 2d 598, 614-19 (S.D. Tex. 2010) (explaining that severe sanctions are not appropriate in the absence of bad faith conduct and a finding of prejudice).

88. The previous version of the Rule did not provide for spoliation sanctions, but instead provided that courts should not impose sanctions on a party for failing to produce electronically stored information "lost as a result of the routine, good faith operation of an electronic information system.” FED. R. CIV. P. 37(e) (2014).

89. Fed. R. CIv. P. 37(e); see, e.g., Orchestratehr, Inc. v. Trombetta, No. 3:13-cv-2110-P, 2016 WL 1555784, at *9-13 (N.D. Tex. 2016) (denying request for adverse inference instruction despite "troubling" evidence concerning deletion of emails, finding that plaintiffs failed to establish defendant acted with the intent required by FRCP 37(e)).

90. Fed. R. Civ. P. 37(e).

91. Id. A court inclined to sanction an attorney for spoliation could rely upon its inherent authority. See supra note 86 . 


\section{SANCTIONING ATTORNEY AND CLIENT CONDUCT IN DOCUMENT DISCOVERY}

The prevailing party in a motion to compel may seek sanctions against opposing counsel and the opposing party. ${ }^{92}$ A party may also seek sanctions on the basis that an opponent has failed or refused to produce documents despite previously being ordered to do so (such as in a scheduling order or an order compelling production). ${ }^{93}$ And as discussed above, sanctions can also be requested for an opponent's spoliation of evidence. ${ }^{94}$ A party can seek sanctions against both opposing counsel and party on the grounds that the party's discovery request, response, or objection violates the certification requirement of FRCP $26(\mathrm{~g}){ }^{95}$

Beyond the FRCP, federal courts have statutory authority to impose sanctions against an attorney for vexatiously increasing the cost of litigation. ${ }^{96}$ In cases involving bad faith and when no other rule provision provides the authority to sanction, federal courts may rely upon their inherent authority to sanction discovery misconduct. ${ }^{97}$

The use of sanctions to address discovery misconduct has increased through the years. In 1983, FRCP 26 was amended with the goal that increased availability of discovery sanctions would end discovery misconduct. ${ }^{98}$ It was not until the dawn of the ediscovery era, though, that federal courts began to sanction

92. FeD. R. Civ. P. 37(a)(5) (if a motion to compel is granted, the party, attorney, or both may be ordered to pay the moving party's expenses of making the motion, including attorneys' fees; if it is denied-such as because the document requests were improper - then the moving party, attorney, or both may be ordered to pay the non-moving party's expenses of opposing the motion).

93. FED. R. CIV. P. 37(b)(2) (party can be sanctioned for not obeying a discovery order, such as a scheduling order consistent with the parties' 26(f) discovery plan or an order compelling discovery under Rule 37(a)); see, e.g., Granados v. Traffic Bar \& Rest., Inc., No. 13 Civ. 0500 (TPG) (JCF), 2016 WL 1317988, at *1, *2 (S.D.N.Y. Mar. 31, 2016) (sanctioning attorney and clients for noncompliance with order compelling production of documents); Porter Bridge Loan Co. v. Hentges, No. 09-CV-593-JED-FHM, 2013 WL 1412372, at *5-7 (N.D. Okla. 2013) (affirming magistrate judge's order sanctioning attorney and client for violating prior court order compelling production of documents); Bd. of Regents of Univ. of Neb. v. BASF Corp., No. 4:04CV3356, 2007 WL 3342423, at *1, *5-6 (D. Neb. Nov. 5, 2007) (sanctioning client for failure to comply with order compelling production, noting the delays caused in the case, loss of confidence that all relevant documents have been produced, and "the gnawing question of whether relevant documents ... [were] destroyed").

94. FED. R. Civ. P. 37(e).

95. FED. R. CIV. P. 26(g)(1)(B), 26(g)(3) (sanctions for improper certification of discovery request, response, or objection).

96. 28 U.S.C. § 1927 (2012) (attorney who "so multiplies the proceedings ... unreasonably and vexatiously" can be required to pay excess costs, expenses, and attorneys' fees).

97. Chambers v. NASCO, 501 U.S. 32, 44-45 (1991).

98. Edward J. Imwinkelried, A New Antidote for an Opponent's Pretrial Discovery Misconduct: Treating the Misconduct at Trial as an Admission by Conduct of the Weakness of the Opponent's Case, 1993 BYU L. REV. 793, 795 ("[T]he [1983] amendments were intended to encourage judges to punish discovery misconduct by imposing sanctions more aggressively. It was hoped that the sanctions 'movement' would discourage obstructionism."). 
discovery misconduct with some frequency ${ }^{99}$ For example, 2009 saw more cases in which parties sought ediscovery sanctions than all years leading up to 2005 combined. ${ }^{100}$ In their seminal article on the increase in discovery sanctions in the ediscovery era, attorneys Dan Willoughby, Rose Hunter Jones, and Gregory Antine asserted: "We identified no case in which a court inclined to impose a sanction was unable to do so because particular rules or statutory requirements were not met."101

\section{Professional Conduct Rules and Discipline Systems}

In most jurisdictions, Rule of Professional Conduct (RPC) 3.4 is the rule most pertinent to document discovery misconduct. ${ }^{102}$ The District of Columbia and every state but California ${ }^{103}$ has adopted a rule patterned on Model Rule of Professional Conduct 3.4 $4^{104}$ (though a handful of adopting states have deleted some of the rule's provisions relevant to document discovery misconduct). ${ }^{105}$ Federal courts typically adopt the professional conduct rules of the state in which the court is located; ${ }^{106}$ thus, most attorneys practicing in federal court are obligated to comply with some version of Model Rule 3.4. ${ }^{107}$

99. Willoughby et al., supra note 3, at 790-91 (describing the significant increase in ediscovery sanctions motions and awards since 2004).

100. Id. at 794 .

101. Id. at 798-99.

102. See Paula Schaefer, State Professional Conduct Rules Concerning Fairness to Opposing Party and Counsel, http://www.pierceprofessionalresponsibility.com/index.asp [https://perma.cc/NJS4-JE54] [hereinafter Schaefer, State Professional Conduct Rules].

103. The California professional conduct rule pertinent to document discovery provides, "A member shall not suppress any evidence that the member or the member's client has a legal obligation to reveal or to produce.” CAl. Rules of Prof'L Conduct R. 5-220 (2015).

104. Schaefer, State Professional Conduct Rules, supra note 102.

105. Id. (showing that Alabama, Maine, and Texas have no provision identical or substantially similar to Model Rule 3.4(d); that Georgia, Illinois, and Pennsylvania have no provision identical or substantially similar to Model Rule 3.4(c) and (d); and that New York's rule does not closely track the language of Model Rule 3.4).

106. See Paula Schaefer, Federal District Court Professional Conduct Rules and Discipline Provisions, http://www.pierceprofessionalresponsibility.com/index.asp [https://perma.cc/NJS4-JE54] [hereinafter Schaefer, Federal Chart]; see, e.g., E.D. TENN. LoC. R. 83.6 (adopting Tennessee rules of professional conduct).

107. Some federal courts have not adopted professional conduct rules. See Schaefer, Federal Chart, supra note 106 (showing that no professional conduct rules have been adopted by the Eastern and Western District of Arkansas, the Northern District of Illinois, the Eastern and Western District of Kentucky, the Northern District of New York, the District of North Dakota, the District of South Dakota, the District of Vermont, the Western District of Virginia, and the Western District of Wisconsin). The professional conduct rule addressing choice of law provides that the "rules of the jurisdiction in which the tribunal sits, unless the rules of the tribunal provide otherwise" apply for conduct in connection with a matter pending before a tribunal. MODEL RULES R. 8.5(b). Thus, the state professional conduct rules for the state in which the court is located would appear to apply in the absence of adopting different rules. 
Model Rule 3.4 addresses all of the major categories of discovery misconduct that were addressed in Part I. ${ }^{108}$ Subpart (a) addresses the issue of spoliation of evidence, as well as failure to produce documents. ${ }^{109}$ It prohibits a lawyer from unlawfully obstructing a party's access to evidence or unlawfully altering, destroying, or concealing evidence. ${ }^{110}$ The next subpart applicable to document discovery is (c), which provides that an attorney shall not "knowingly disobey an obligation under the rules of a tribunal," other than an open refusal to do so asserting no valid obligation exists. ${ }^{111}$ Subpart (d) deals with improper requests and responses to document discovery, prohibiting "mak[ing] a frivolous discovery request or fail[ing] to make reasonably diligent effort to comply with a legally proper discovery request by an opposing party." 112 In short, RPC 3.4 is not just a hortatory rule. It is specific and its violation is susceptible to being proven in a disciplinary proceeding. ${ }^{113}$

Both judges and attorneys have an obligation to report professional misconduct to disciplinary authorities in defined circumstances. ${ }^{114}$ Discovery misconduct that occurs in federal court could be reported to (and ultimately disciplined by) the federal court's own disciplinary system or the disciplinary authorities in the state where the attorney is licensed. ${ }^{115} \mathrm{~A}$ federal court has the authority to discipline attorneys admitted to practice before the court. ${ }^{116}$ Most federal district courts have adopted local rules establishing a disciplinary system. ${ }^{117}$ Only a

108. See Paul W. Grimm \& Joel P. Williams, Ethical Issues Associated with Preserving, Accessing, Discovering, and Using Electronically Stored Information, 14 FIDELITY L.J. 57, 58-63 (2008) (explaining that Rule 3.4(a) is most pertinent to the issue of ESI preservation).

109. Model Rules R. 3.4(a) (“A lawyer shall not unlawfully obstruct another party's access to evidence or unlawfully alter, destroy or conceal a document or other material having potential evidentiary value. A lawyer shall not counsel or assist another person to do any such act.").

110. Model Rules R. 3.4(a).

111. Model Rules R. 3.4(c).

112. Model Rules R. 3.4(d).

113. Fred C. Zacharias, What Lawyers Do When Nobody's Watching: Legal Advertising as a Case Study of the Impact of Underenforced Professional Rules, 87 IowA L. REV. 971, 997-1001 (2002) (discussing hortatory professional conduct rules that are unenforceable and enforceable rules that are under-enforced) [hereinafter Zacharias, Nobody's Watching].

114. Model Rules R. 8.3; Code of Conduct for U.S. Judges, Canon 3(B)(5); see also infra Part IV.

115. See, e.g., In re Lacy, 353 B.R. 264, 280 (D. Colo. 2006) (referring California-licensed attorney to California bar and Committee on Conduct for the U.S. District Court for the District of Colorado based on determination that counsel's conduct may violate Colorado professional conduct rules).

116. See generally Jason Mehta, The Development of Federal Professional Responsibility Rules: The Effect of Institutional Choice on Rule Outcomes, 6 CARdozo PuB. L. PoL'y \& Ethics J. 57, 69-70 (2007) (describing a federal court's inherent authority to regulate attorney conduct and authority under the Rules Enabling Act to adopt rules governing attorney conduct).

117. See Schaefer, Federal Chart, supra note 106. Many of these rules describe to whom a report should be made (often the Chief Judge), the process for investigating the attorney's conduct, and the procedures for a hearing on the charge. See, e.g., M.D. GA. Loc. R. 83.2.3 (describing referral of disciplinary matters to the Grievance Committee for investigation and the procedure if the committee determines probable cause exists). Other rules in this category specifically permit the judge presiding in the pending matter to address the misconduct for purposes of imposing discipline. See, e.g., C.D. CAL. LOC. R. 83-3.1. 
small number of federal district courts have adopted no disciplinary system by local rule. ${ }^{118}$ Further, each state's highest court authorizes a body to investigate complaints against attorneys, determine if disciplinary charges are warranted, and if so, file and prosecute disciplinary charges. ${ }^{119}$ State disciplinary authorities may discipline for conduct that occurs in federal court. ${ }^{120}$ Regardless of which disciplinary authority first disciplines the attorney, reciprocal discipline is likely to occur in any other licensing jurisdictions or courts in which the attorney is admitted to practice. ${ }^{121}$

Discipline possibilities generally include private reprimand or censure, public reprimand or censure, suspension, and disbarment. ${ }^{122}$ Diversion is also a possibility if permitted under court rules. Through a diversion agreement, an attorney may be able to avoid discipline by participating in an educational program intended to teach the attorney how to avoid the misconduct in the future. ${ }^{123}$

\section{The (Apparently) Rare Use of the Discipline System to Address Discovery Misconduct in Federal CourT}

There are some limitations on the ability to know the full extent of disciplinary referrals and discipline decisions. ${ }^{124}$ Disciplinary complaints and referrals to disciplinary authorities can be made confidentially. ${ }^{125}$ Further, a decision imposing — or declining to impose-discipline does not necessarily result in a

118. The following courts have not adopted local rules to create an internal disciplinary process: District of Alaska, Eastern District of Arkansas, Southern District of Indiana, District of Massachusetts, Western District of North Carolina, District of Vermont, Northern and Southern Districts of West Virginia, and Eastern District of Wisconsin. Schaefer, Federal Chart, supra note 106.

119. See, e.g., Tenn. Sup. Cт. R. 9, $\$ 4.5$ (conferring to the Board of Professional Responsibility the power to investigate alleged grounds for attorney discipline and to adopt procedures for and monitor investigations and formal proceedings by Disciplinary Counsel and hearing panels conducted pursuant to the Rule). See generally Debra Moss Curtis, Attorney Discipline Nationwide: A Comparative Analysis of Process and Statistics, $35 \mathrm{~J}$. Legal Prof. 209, 210 (2011) (explaining that state supreme courts adopt professional conduct rules and create and administer an enforcement process).

120. Model Rules R. 8.5(a).

121. See Model Rules for LaWyer Disciplinary Enforcement R. 22 (2002).

122. See, e.g., TEnN. Sup. CT. R. 9, § 12 (listing types of discipline); E.D. Tenn. Loc. R. 83.7 (listing possible discipline as disbarment, suspension, reprimand, or other "appropriate and just" discipline).

123. See, e.g., D. MD. Loc. R. 705(1)(h) (describing possible conditions of a diversion agreement).

124. See generally Michael S. Frisch, Web Access to Bar Discipline Information: The Critical Component of Transparency, Legal PROF. BLOG (June 26, 2016), http://lawprofessors.typepad.com/legal_profession/2016/06/ the-web-page-of-the-colorado-supreme-court-was-recently-redesigned-as-noted-below-by-james-c-coyleattorney-regulation-cou.html [http://perma.cc/QX62-5RKN].

125. See, e.g., Comm. on the Conduct of Att'ys v. Oliver, 510 F.3d 1219, 1221-25 (10th Cir. 2007) (disciplinary proceedings were initiated when U.S. district court judge issued a sealed complaint referring attorney to Utah State Bar Office of Professional Conduct and District of Utah Disciplinary Panel). 
reported decision. ${ }^{126}$ This makes it difficult to know the full extent of disciplinary proceedings related to discovery misconduct.

That being said, the evidence suggests that discipline referrals and the imposition of discipline for document discovery misconduct that occurred in federal court are exceedingly rare. ${ }^{127}$

Though discipline referrals can be made confidentially, one might reasonably expect a judge planning to make such a referral to signal this in an order addressing the underlying discovery misconduct. ${ }^{128}$ In federal court orders available through Westlaw, there are very few referrals to disciplinary authorities $^{129}$ or show cause orders ${ }^{130}$ arising out of attorney document discovery misconduct. There are a handful of additional document discovery cases in which judges discuss the applicable professional conduct rules without referencing the possibility of a referral for discipline. ${ }^{131}$

126. One reason is that disciplinary matters are sometimes treated as confidential unless the case results in public discipline. See, e.g., M.D. GA. Loc. R. 83.2.3 (describing confidentiality of disciplinary records "unless and until otherwise ordered by the Court"). In state disciplinary proceedings, discipline may not result in a reported decision unless one of the parties appeals. The decision imposing discipline may be difficult to find through a disciplinary authority's website. See supra note 124.

127. Westlaw's advanced search feature was used to retrieve cases in all federal and state courts that included the terms "discovery" and "3.4" (the professional conduct rule most likely to be violated in every jurisdiction other than California courts). In an effort to identify California cases involving referrals or discipline and violations of California Rule of Professional Conduct 5-220 (concerning suppressing evidence), searches included the terms "discovery" and "5-220." In searching for state cases that originated in federal court, search terms also included "U.S. or federal." These searches retrieved hundreds of decisions that were manually reviewed to determine whether they involved discipline-related matters and discovery misconduct; the vast majority did not.

128. Judith A. McMorrow et al., Judicial Attitudes Toward Confronting Attorney Misconduct: A View From the Reported Decisions, 32 Hofstra L. REv. 1425, 1438 (2004) (asserting that forwarding an opinion to disciplinary authorities appears to be the most common method of public referral, but noting that a court's discipline referral need not occur in a reported decision).

129. Steward v. Steward, 529 B.R. 903, 913-14 (E.D. Mo. 2015) (referring, by the bankruptcy court, attorneys to state and federal court disciplinary authorities for a variety of misconduct, including failing to produce discovery documents in violation of court order); Qualcomm, Inc. v. Broadcom Corp., No. 05cv1958-B (BLM), 2008 WL 66932, at *18 (S.D. Cal. Jan. 7, 2008) (sanctioning attorneys for document discovery misconduct by referring them to the California State Bar for discipline and requiring them to attend a program to determine failures in the case management and discovery protocols in the case), vacated in part, No. 05CV1958-RMB (BLM), 2008 WL 638108, at *3 (S.D. Cal. Mar. 5, 2008) (sanctioning attorneys' portion of order vacated to allow attorneys to introduce attorney-client privileged communications in their defense), appeal dismissed, No. 05cv1958-B (BLM), 2010 WL 1336937, at*2 (S.D. Cal. Apr. 2, 2010) (declining to impose sanctions against attorneys).

130. In re Marshall, No. 3:15-MC-88-JWD, 2016 WL 81484, at*1 (M.D. La. Jan. 6, 2016) (ordering attorney to show cause why he should not be sanctioned for violating court rules and Louisiana Rules of Professional Conduct); In re Gluck, 114 F. Supp. 3d 57, 58 (E.D.N.Y. 2015) (issuing, by district court's Committee on Grievances, two orders to show cause why attorney should not be disciplined for misconduct in multiple federal cases).

131. See, e.g., Witt v. GC Servs. Ltd. P'ship, 307 F.R.D. 554, 556 \& n.2 (D. Colo. 2014); 1100 W., LLC v. Red Spot Paint \& Varnish Co., No. 1:05-cv-1670-LJM-JMS, 2009 WL 1605118, at *28 (S.D. Ind. June 5, 2009); Mancia v. Mayflower Textile Servs. Co., 253 F.R.D. 354, 362-63, 362 n.6 (D. Md. 2008); White v. Office of the 
Ultimately, there are very few federal court decisions addressing the imposition of discipline for discovery misconduct. When the issue of document discovery misconduct has been considered, it most often arises in the context of an attorney's numerous professional conduct violations, with document discovery misconduct receiving only cursory attention in the court's decision. ${ }^{132}$ It appears there are only two federal disciplinary cases that include any extended discussion of attorneys' misconduct related to document discovery. ${ }^{133}$

Similarly, only a small number of state court decisions have addressed attorney discipline for document discovery misconduct that occurred in federal court. These cases contain a brief discussion of how attorneys failed to respond to discovery requests or comply with discovery orders in a federal case, often in the context of multiple other rule violations. ${ }^{134}$ One state court decision involves discipline for failure to produce documents in a federal case in which the attorneys were defendants and not counsel. ${ }^{135}$

Pub. Def., 170 F.R.D. 138, 147 (D. Md. 1997); Sanders v. Toyo Umpanki Co., Civ. A. No. 7:92-2402-3, 1994 WL 902775 , at $* 2$ (D.S.C. Feb. 1, 1994).

132. See, e.g., Comm. on the Conduct of Att'ys v. Oliver, 510 F.3d 1219, 1221-25 (10th Cir. 2007) (affirming District of Nevada's one-year suspension, three-year probation, and public reprimand of attorney for misconduct in twenty-seven cases, including not responding to discovery requests); In re Marshall, $2016 \mathrm{WL}$ 81484 , at $* 1, * 8$ (suspending attorney and ordering completion of six hours of ethics continuing legal education for misconduct in two cases, including document discovery misconduct); Steward, 529 B.R. at 913 (referring attorneys to state and federal court disciplinary authorities, bankruptcy judge also relies upon inherent power to suspend attorneys for making false statements, including statements related to discovery); In re Gluck, $114 \mathrm{~F}$. Supp. 3d at 59-61 (reprimanding publicly the attorney for misconduct in eleven cases, including failing to comply with court orders, including discovery related orders).

133. The cases are related. The attorneys were a partner and associate who did not produce responsive documents on a key issue - employment of their client—during discovery. Both were suspended for one year. In re Gilly, 976 F. Supp. 2d 471, 480 (S.D.N.Y. 2013); In re Filosa, 976 F. Supp. 2d 460, 471 (S.D.N.Y. 2013).

134. Bd. of Prof'l Resp. v. Richard, 335 P.3d 1036, 1041-45, 1055 (Wyo. 2014) (addressing discovery misconduct in multiple cases, including federal case in which the attorney failed to produce responsive documents); In re Arbuckle, 156 P.3d 668, 669-70 (Kan. 2007) (attorney was referred to disciplinary authorities by his own client after the client's case was dismissed by federal court, in part for attorney's failure to comply with order compelling discovery responses); In re Devkota, 123 P.3d 1289, 1289-93 (Kan. 2005) (censuring attorney for, among other things, failing to timely respond to requests for production in federal court); In re McFarland, 600 S.E.2d 537, 537-40 (S.C. 2004) (reprimanding publicly attorney for misconduct that included failure to comply with a federal court's order regarding discovery); Ligon v. Price, 200 S.W.3d 417, 424-26 (Ark. 2004) (attorney did not respond to requests for production or subsequent order compelling production of documents in federal court by attorney); In re Boone, 7 P.3d 270, 282-83 (Kan. 2000) (disciplining the attorney for conduct in multiple federal and state court cases, including violations of RPC 3.4 related to document discovery).

135. In re Carey, 89 S.W.2d 477, 499-504 (Mo. 2002). 


\section{BArriers to Attorneys And Judges Reporting Counsel's DisCOVERY Misconduct TO DisCIPLINARY AUTHORITIES}

One explanation for the lack of discipline for discovery misconduct in federal court is that it is not being reported to disciplinary authorities. ${ }^{136}$ While clients are most likely to complain about an attorney's lack of communication or incompetence, ${ }^{137}$ discovery misconduct is different. Because it harms opposing parties and the court system, the most likely reporters are opposing counsel and judges. The following discussion considers these groups separately to understand why they may be disinclined to report discovery misconduct to disciplinary authorities.

\section{A. EXPLANATIONS FOR ATTORNEYS UNDERREPORTING MISCONDUCT BY OPPOSING COUNSEL}

Jurisdictions with a professional conduct rule based on Model Rule 8.3 require an attorney who "knows" of another lawyer's violation of professional conduct rules to report that violation to appropriate authorities if the rule violation "raises a substantial question as to that lawyer's honesty, trustworthiness or fitness as a lawyer." ${ }^{138}$ A report is not required if it would violate the confidentiality rule (Rule 1.6), ${ }^{139}$ but client consent to reporting opposing counsel's conduct alleviates any confidentiality concerns. ${ }^{140}$

Despite the mandatory reporting duty if the rule's standard is met, the standard is flexible enough that a lawyer disinclined to report can justify that decision. ${ }^{141}$ A lawyer may reason that he does not necessarily "know" that opposing counsel violated a professional conduct rule, or she may rationalize a decision not to report because the conduct, though a rule violation, does not raise a substantial question of honesty, trustworthiness, or fitness. ${ }^{142}$ Further, the confidentiality exception allows attorneys the leeway to avoid reporting by not seeking client

136. Arthur Greenbaum, Judicial Reporting of Lawyer Misconduct, 77 UMKC L. REv. 537, 539-40 (2009) ("[C]onventional wisdom suggests that [a judge's duty to report lawyer misconduct] is still a duty that is largely ignored.").

137. The most common complaints to disciplinary authorities and the most common basis for discipline is that a lawyer harmed his or her own client. Jennifer Gerarda Brown \& Liana G.T. Wolf, The Paradox and Promise of Restorative Attorney Discipline, 12 NEv. L.J. 253, 259 (2012).

138. Model Rules R. 8.3(a).

139. Model Rules R. 8.3(c).

140. Model Rules R. 1.6(a).

141. Nikki A. Ott \& Heather F. Newton, A Current Look at Model Rule 8.3: How Is It Used and What Are Courts Doing About It?, 16 Geo. J. Legal Eтhics 747, 749-54 (2003) (describing the many reasons lawyers are reluctant to report professional misconduct of "one of their own").

142. Id. at 751-52 (describing discovery misconduct as an example of a scenario that lawyers may view as not clearly raising a "substantial" question of lawyer honesty, trustworthiness, and fitness). 
consent. ${ }^{143}$ Because of the flexibility of the standard for mandatory reporting, attorneys know that discipline for their violation of Rule 8.3 is unlikely. ${ }^{144}$ And when discipline is unlikely for failure to take action that lawyers are reluctant to take, there is little incentive to act. ${ }^{145}$

There is reason to believe that lawyers are, indeed, reluctant to report professional misconduct. ${ }^{146}$ One frequently cited reason lawyers are disinclined to report is that they do not want to be perceived as snitches. ${ }^{147}$ Lawyers fear reporting misconduct will hurt their professional reputation with other lawyers. ${ }^{148}$ They may also be reluctant to report misconduct because they identify with the conduct of their opposing counsel. Perhaps lawyers are willing to seek sanctions but not discipline ${ }^{149}$ because they view the two differently; sanctions do not necessarily target opposing counsel ${ }^{150}$ and are more often awarded against the opposing party than opposing counsel. ${ }^{151}$

Further, there are some practical explanations for the lack of reporting. Uncompensated time and effort is required to file a disciplinary complaint against another lawyer. ${ }^{152}$ And lawyers may believe that if the misconduct truly justifies a referral for discipline, the judge-who has the same knowledge of the miscon-

143. Because all information "related to the representation of the client" is covered by the confidentiality obligation, it is irrelevant that the information about opposing counsel's discovery misconduct is not privileged; it still must be kept in confidence. See Model Rules R. 1.6(a).

144. Ott \& Newton, supra note 141, at 755 (noting the scarcity of discipline against attorneys for failing to report another lawyer's professional misconduct).

145. Conversely, when discipline is foreseeable for a failure to report, attorneys are more likely to take action under RPC 8.3. See Seth Ellis \& Jeffrey R. Hanes, The 20 Year Anniversary of Himmel: Brushing Up on Your Duty to Report Attorney Misconduct, DCBA BRIEF, March 2009, at 16, 16 (explaining that in the year after the Illinois Supreme Court suspended attorney James Himmel for failing to report attorney misconduct under RPC 8.3 , reports of attorney misconduct increased from 154 cases to 922 cases).

146. See R. Sadler Bailey, Using the Rules of Ethics to Move Your Case to Trial, 2 ATLA Ann. Convention 1353, at *4 (2006) (noting that most attorneys do not use ethics rules to combat discovery abuse); John Freeman, If It's Broke, Fix It, S.C. LAW., Jan./Feb. 1994, at 6 (describing "abusive discovery" as a pervasive problem that could be addressed by Rule 3.4, but "the issue is whether lawyers have the will to use it").

147. A. Rebecca Williams, Current Development, An Inside Job: Using In-Court Sting Operations to Uncover Corruption in an Inadequate Self-Regulating System, 28 GEO. J. LEGAL EthICS 969, 977 (2015) (describing how "anti-snitching culture" contributes to lawyers under-reporting misconduct); Michael J. Burwick, Note, You Dirty Rat!! Model Rule 8.3 and Mandatory Reporting of Attorney Misconduct, 8 GEO. J. Legal Ethics 137, 143 (1994) (noting a commentator's description of a reporting rule as a "snitch" rule); Ott \& Newton, supra note 141, at 753 (describing lawyer fear that reporting professional misconduct will result in being "labeled a snitch" and could impact the reporting lawyer's reputation).

148. Id.

149. Bailey, supra note 146 , at $* 4$ (asserting that in response to discovery misconduct, it is common to file a motion to compel and seek sanctions, but not to report to disciplinary authorities).

150. Monetary sanctions available under the FRCP can be entered against a party, a lawyer, or both. FED. R. Civ. P. 26(g), 37(a)(5)(A), 37(a)(5)(B), 37(b)(2)(C).

151. Willoughby et al., supra note 3, at 815-18 (detailing empirical evidence that clients are sanctioned for discovery misconduct more often than lawyers, and when lawyers are sanctioned, clients are typically sanctioned as well).

152. Ott \& Newton, supra note 141, at 754 (explaining that the effort required to report lawyer misconduct acts as a disincentive to reporting). 
duct and will not be perceived as having an "ax to grind" with opposing counsel-is in a better position to make the referral. ${ }^{153}$ Finally, attorneys may perceive that their complaints against opposing counsel would be taken less seriously than that of a client harmed by his or her own attorney. ${ }^{154}$ There is reason to believe lawyers may be correct in this belief.

\section{B. EXPLANATIONS FOR JUDGES UNDERREPORTING ATTORNEY DISCOVERY MISCONDUCT}

Under the Code of Conduct for U.S. Judges, a judge "should" take "appropriate action" when the judge has "reliable evidence indicating the likelihood" that a lawyer violated professional conduct rules. ${ }^{155}$ Commentary to the rule explains that "appropriate action" may include "direct communication" with the lawyer, "other direct action," "reporting the conduct to the appropriate authorities," or in the case of substance abuse, referring the lawyer to a lawyer's assistance program. $^{156}$

Based on the variety of "appropriate actions" that may be taken under the Code of Conduct, federal judges may believe that pointing out a lawyer's discovery misconduct is sufficient. ${ }^{157}$ Even in the case of egregious misconduct, a judge may believe that sanctioning an attorney is more efficient than instigating a satellite proceeding, ${ }^{158}$ thus making a discipline referral unnecessary. ${ }^{159}$ Finally, the judge may be disinclined to make a discipline referral because-perhaps based on the judge's own practice experience-the judge identifies with the attorney ${ }^{160}$ and does not want to harm the attorney's reputation. ${ }^{161}$

153. Greenbaum, supra note 136, at 550 (asserting that if disciplinary authorities give more deference to judges' reports of misconduct it is probably justified because the judge "rightly has more credibility than ... a lawyer adversary" and "the judge is less likely to have an 'ax to grind" with the reported lawyer").

154. Brown \& Wolf, supra note 137, at 262 (noting that a third party who files a disciplinary complaint does not "suffer the breach of trust and loss of relationship that a former client does").

155. Code of Conduct for U.S. Judges, Canon 3(B)(5).

156. Id. at Commentary.

157. McMorrow et al., supra note 128, at 1432 (explaining that "appropriate action" is "so open-ended as to offer no meaningful guidance to judges").

158. Id. at 1427-28 (asserting that efficiency concerns are likely a dominant factor in how judges address attorney misconduct in litigation); Michael S. McGinniss, Sending the Message: Using Technology to Support Judicial Reporting of Lawyer Misconduct to State Disciplinary Agencies, J. Prof. Law., 2013, at 37, 52 (noting efficiency concerns as a reason for underreporting); see also CODE OF CONDUCT FOR U.S. JudGES, Canon 3(B)(5), Commentary (noting that communicating with the lawyer and "other direct action" are appropriate responses to attorney misconduct).

159. See, e.g., GMAC Bank v. HTFC Corp., 248 F.R.D. 182, 198 n.23 (E.D. Penn. 2008) ("The Court will refrain from referring this matter to a disciplinary authority in this case ... because the sanctions imposed pursuant to the [FRCP] are sufficient to achieve the remedial purpose of the Rules of Professional Conduct.").

160. See Mehta, supra note 116, at 95 (asserting that judges will approach issues of attorney conduct rulemaking "with some sort of bias towards their particular experience in the law"). See generally BENJAMIN H. Barton, The Lawyer-Judge Bias in the American Legal System (Cambridge Univ. Press 2011).

161. See McMorrow et al., supra note 128, at 1428 (explaining judges' motivation to protect attorneys' reputations when addressing attorney misconduct). Judges are reluctant to impose discovery sanctions for the 


\section{The Case for Appropriate, Consistent Use of the Discipline System to AdDRESS DOCUMENT DisCOVERY MisconduCT}

Refereeing a constant stream of discovery disputes-many involving attorney conduct in violation of professional conduct rules - places a tremendous strain on judicial resources. If the same judges were to appropriately and consistently use the attorney discipline system, attorneys would likely get the message and change. This Part explains when discipline is appropriate, how judges can use the discipline system consistently to effect change, and why discipline may be more effective than sanctions alone.

\section{A. APPROPRIATE USE OF THE DISCIPLINE SYSTEM: WHICH DISCOVERY CONDUCT SHOULD (AND SHOULD NOT) RESULT IN DISCIPLINE?}

Not all discovery disputes involve attorney misconduct. ${ }^{162}$ As long as an attorney is transparent with opposing counsel and the court about an arguably legitimate basis for requesting documents or objecting to an opponent's requests, then professional discipline generally is not appropriate. Regarding the requesting attorney, RPC 3.4(d) permits discipline only for making a "frivolous" discovery request. ${ }^{163}$ Even a request that is found to be beyond the scope of discovery (based on the court's determination that the request is not proportionate, for example) typically does not rise to the level of "frivolous." ${ }^{164}$ As to the objecting party, knowingly disobeying an obligation under court rules (such as the obligation to produce documents) is misconduct, "except for an open refusal based on an assertion that no valid obligation exists."165 In the transparent objection scenario, the attorney's conduct is an open refusal falling within the exception to the professional conduct rule. ${ }^{166}$ It is good policy not to discipline an attorney who transparently makes even wrong-headed objections because it

same reasons. See, e.g., Sec. Nat'1 Bank of Sioux City, IA v. Jones Day, 800 F.3d 936, 944 (8th Cir. 2015) (citing In re Prudential Ins. Co. Am. Sales Practice Litig. Actions, 278 F.3d 175, 191 (3d Cir. 2002)) (noting the "tangible effect" sanctions can have on an attorney's career).

162. Undoubtedly, discovery disputes add to the cost of litigation and to the frustration of the parties and the court. Many of these disputes could be avoided if opposing counsel could cooperate to resolve their disputes. But discipline is not a tool for reining in legitimate, though costly, discovery disputes.

163. Model Rules R. 3.4(d).

164. Under the FRCP, a document request is arguably improper if it seeks documents beyond the scope of discovery. See FED. R. Civ. P. 26(b)(1), 34. But there is no way to test what is beyond the scope of discovery without making the request and (if agreement cannot be reached) seeking the court's input through a motion to compel. See FED. R. CIV. P. 37.

165. Model Rules R. 3.4(c).

166. See, e.g., DiSante v. Litton Indus. Automation Sys. Inc., Nos. 89-1931, 89-1968, 1991 WL 37827, at *5 (6th Cir. Mar. 19, 1991) (disagreeing with the district court's suggestion that a party who objected to discovery requests violated professional conduct rules, explaining that 'defendant chose to resist vigorously plaintiffs' request for document production.... Yet there is nothing to suggest that defendant's strategy decision was without any legal or factual basis ....”). 
encourages openness in articulating objections, which helps resolve disputes more efficiently.

Discovery conduct that should be disciplined generally falls into one of two categories: (1) misleading an opposing party and (2) intentionally or negligently failing to perform a duty owed to an opposing party.

A lack of transparency in objections falls into the first category. An attorney's non-specific, boilerplate objections - such that an opposing party will not know whether documents were withheld on the basis of the objections-should result in discipline. ${ }^{167}$ The FRCP requires such transparency so that a requesting party can challenge the objection and seek production of the document. ${ }^{168}$ But no meaningful challenge can be made if every request is met with boilerplate objections and ambiguous statements about whether any documents were withheld. This conduct is pervasive, frustrates the discovery process, and violates all of the discovery-related provisions of RPC 3.4. ${ }^{169}$

In the second category of misconduct appropriate for discipline, an attorney's intentional or negligent failure to identify and timely produce responsive documents should result in a discipline referral. ${ }^{170}$ Each of the discovery-related provisions of RPC 3.4 prohibits this conduct. ${ }^{171}$ If there is any doubt that even negligent failure to identify and produce responsive documents should result in discipline, RPC 3.4(d) explicitly states that it is misconduct for an attorney to "fail to make [a] reasonably diligent effort to comply" with a proper discovery request. ${ }^{172}$

Also in the second category, an attorney's negligent or intentional role in spoliation of evidence is another appropriate basis for discipline. ${ }^{173}$ Attorneys are in a better position than clients to understand the steps that must be taken to fulfill the common law duty of preservation. Rule 3.4 provides that it is misconduct for an attorney to "unlawfully obstruct[]" a party's access to evidence or to "unlawfully alter, destroy or conceal a document . . . having potential evidentiary value." 174

A final type of misconduct in the second category is an attorney's violation of a discovery-related court order. ${ }^{175}$ Such an order likely will be a scheduling order

167. See supra notes $67-75$ and accompanying text.

168. Fed. R. Civ. P. 34(b)(2)(B)-(C) (requiring specificity in objections and statement of whether material is withheld based on objections), 37(a)(3)(B) (motion to compel discovery response).

169. Model Rules R. 3.4(a) (shall not unlawfully obstruct access to evidence or conceal a document), 3.4(c) (shall not knowingly disobey court rules, except for an open refusal), 3.4(d) (shall not fail to make a reasonably diligent effort to comply with a proper request for discovery).

170. See supra notes $77-78$ and accompanying text.

171. See supra note 169 .

172. Model Rules R. 3.4(d).

173. See supra notes $81-85$ and accompanying text.

174. Model Rules R. 3.4(a).

175. See generally supra note 93 and accompanying text (regarding sanctions for violating court order). 
(that details the parties' obligations in discovery) ${ }^{176}$ or an order compelling the production of documents (following a prior discovery dispute). ${ }^{177}$ In either of those scenarios, the obligation arises out of court rules as applied to the facts of the case. ${ }^{178}$ Thus, such a violation would likely also be a violation of RPC $3.4(\mathrm{c}) .^{179}$

Discipline is critical in this second category. In the context of producing documents, preserving evidence, and complying with court orders, the opposing party has no choice but to rely upon the competence and diligence of opposing counsel. ${ }^{180}$ While a client can sue a lawyer for professional negligence for violating the duty of care, ${ }^{181}$ an opposing party generally cannot. ${ }^{182}$ Sanctions for violating the rules of discovery have not been an adequate deterrent to violating this obligation. ${ }^{183}$ And the new FRCP provision governing spoliation of electronic evidence does not even address attorney sanctions. ${ }^{184}$ Because the law cannot and has not deterred attorneys from violating a duty of competence owed to opposing parties in discovery, discipline should step in to play that role.

Some may be concerned that discipline for discovery misconduct could cause some attorneys to be overly cautious in their advocacy, to the detriment of their clients. But zealous advocacy involves making the best argument for the client's position, letting an opponent do the same, and if the parties cannot reach a resolution, allowing the dispute to be decided by the judge. ${ }^{185}$ Making discipline referrals in the scenarios described in this section (a lack of transparency in

176. See, e.g., Sun River Energy, Inc. v. Nelson, 800 F.3d 1219, 1228-30 (10th Cir. 2015) (affirming sanction against attorney for violating discovery obligation in scheduling order); Mahoney v. Yamaha Motor Corp. U.S.A., 290 F.R.D. 363, 368-69 (E.D.N.Y. 2013) (imposing sanctions against attorney for violating discovery obligations in scheduling and pretrial orders).

177. See, e.g., In re Steward, 529 B.R. 903, 909-10 (E.D. Mo. 2015) (attorney ignored court order compelling production of discovery); Porter Bridge Loan Co. v. Hentges, No. 09-CV-593-JED-FHM, 2013 WL 1412372 , at *5 (N.D. Okla. Apr. 8, 2013) (describing the "extraordinary delay and expense" necessitated by party failing to comply with court's prior order compelling discovery responses); Wachtel v. Health Net, Inc., 239 F.R.D. 81, 94 (D.N.J. 2006) (attorneys violated judge's order compelling discovery).

178. See Bd. of Regents of Univ. of Neb. v. BASF Corp., No. 4:04CV3356, 2007 WL 3342423, at*5 (D. Neb. Nov. 5, 2007) (explaining the relationship between counsel's failure to take affirmative steps to ensure production of documents in compliance with court order and counsel's failure to meet obligations under the FRCP).

179. See Model Rules R. 3.4(c).

180. See supra notes 59-61 and accompanying text.

181. Restatement of the Law Governing Lawyers $\S 48$ (2000) (describing a cause of action for professional negligence for lawyer's failure to exercise care-namely, the "competence and diligence normally exercised by lawyers in similar circumstances").

182. The Restatement describes the limited circumstances in which a lawyer has liability to non-clients for breaching the duty of care. Lawyer conduct in discovery is not among the circumstances described as a basis for liability to a non-client. See id. $\S 51$.

183. See generally supra Part I (describing the current state of attorney misconduct in conducting document discovery in federal court).

184. See Fed. R. Civ. P. 37(e).

185. Paula Schaefer, Harming Business Clients with Zealous Advocacy: Rethinking the Attorney Advisor's Touchstone, 38 FLA. ST. U. L. REV. 251, 262 (2011). 
objections, a failure to search for and produce requested documents, a failure to competently address preservation of evidence, and non-compliance with discovery orders) facilitates zealous advocacy because it allows both parties to know and address the evidence in the case. ${ }^{186}$ Attorneys engaged in such misconduct are not being advocates in a dispute. ${ }^{187}$ They are playing a part in hiding or withholding documents or misleading their opponents. Such conduct has never been recognized as appropriate advocacy. ${ }^{188}$

\section{B. CONSISTENCY AND BEHAVIORAL LEGAL ETHICS}

In the current discovery environment, there are various reasons attorneys may not comply with the discovery rules. At one end of the spectrum, some attorneys may not know the rules. At the other extreme, attorneys may intentionally violate the rules, perhaps based on a rational decision that the benefits outweigh the costs. $^{189}$

Consistency on two discipline-related fronts could impact both of these explanations for discovery misconduct. Judges should consistently (1) educate attorneys about discovery ethics expectations, including telling attorneys the disciplinary consequences of violating the rules, and (2) impose consequences - in the nature of disciplinary referrals and ultimately discipline-when attorneys violate those obligations. For attorneys ignorant of their professional duties in discovery, the education piece should direct them toward appropriate conduct. For attorneys making a calculated decision to engage in misconduct, consistent adverse consequences could give them the incentive they need to change their ways - or punishment if they will not change.

In between the two extremes are attorneys who understand their discovery obligations and have good intentions but nonetheless engage in misconduct. Behavioral legal ethics - the study of how behavioral science impacts attorney

186. As U.S. Magistrate Judge Grimm explains in Mancia v. Mayflower, "[T] here is nothing inherent in [the adversary system] that precludes cooperation between the parties and their attorneys during the litigation process to achieve orderly and cost effective discovery of the competing facts on which the [adversary] system depends." Mancia v. Mayflower Textile Servs. Co., 253 F.R.D. 354, 361 (D. Md. 2008) (emphasis added); see also 1100 W., LLC v. Red Spot Paint \& Varnish Co., No. 1:05-cv-1670-LJM-JMS, 2009 WL 1605118, at *33 (S.D. Ind. June 5, 2009) (explaining that defendant's attorneys should have made a complete disclosure in discovery "so that the lawyers could argue and a fact finder could determine the merits of the case") (emphasis added).

187. See, e.g., 1100 W., $2009 \mathrm{WL} 1605118$, at *34 (in sanctioning law firm for failure to produce responsive documents, court noted, "Being a zealous lawyer does not mean zealously believing your client in light of evidence to the contrary").

188. Model Rules R. 3.4 cmt. 1 ("Fair competition in the adversary system is secured by prohibitions against destruction or concealment of evidence, . . obstructive tactics in discovery procedure, and the like.").

189. See Fred C. Zacharias, The Purposes of Lawyer Discipline, 45 WM. \& MARY L. Rev. 675, 739 (2003) (asserting that not enforcing professional conduct rules may encourage lawyers' non-compliance with those rules) [hereinafter Zacharias, Purposes]. 
conduct - can provide insight into this attorney behavior. ${ }^{190}$ A cognitive bias or mindset of zealous advocacy can shade how attorneys view the appropriateness of their conduct in discovery. ${ }^{191}$ For example, a document that an objective third party would see as responsive to a document request may be viewed as non-responsive through the partisan eyes of the zealous advocate. ${ }^{192}$ Further, this bias may cause lawyers to rationalize their more questionable discovery conduct (from boilerplate objections to delayed document productions) as what is expected of a zealous advocate (rather than the violation of law and ethics rules that it actually is). ${ }^{193}$ The zealous advocacy mindset can contribute to "ethical fading"-becoming so acculturated to certain practices that the ethical component fades out of consideration, making unethical decisions easier. ${ }^{194}$ A lawyer's personal interests (like the desire to please a client) ${ }^{195}$ or situational pressures (such as to act in conformity with the conduct of other firm lawyers) ${ }^{196}$ can contribute to the ways that lawyers interpret and resolve ethical dilemmas in discovery.

Judges can counteract these factors - and perhaps even harness the power of behavioral science-by consistently educating attorneys about discovery expec-

190. See, e.g., Tigran W. Eldred, Insights from Psychology: Teaching Behavioral Legal Ethics as a Core Element of Professional Responsibility, 2016 Mich. ST. L. REv. 757, 759 (explaining that the central idea of behavioral legal ethics is that "unethical conduct is frequently the product of psychological factors that occur largely outside of the conscious awareness of the decision-maker"); Andrew M. Perlman, A Behavioral Theory of Legal Ethics, 90 IND. L.J. 1639, 1640 (2015) (asserting that situational factors, like the lawyer's partisan role, can result in unethical conduct); Jennifer K. Robbennolt \& Jean R. Sternlight, Behavioral Legal Ethics, 45 ARIz. ST. L.J. 1107, 1111-12 (2013) (explaining insights that can be gained from psychology concerning why attorneys behave unethically).

191. See Perlman, supra note 190, at 1651 (making the case that partisanship research supports the conclusion that people in a partisan role have difficulty assessing information objectively); Cassandra Burke Robertson, Judgment, Identity, and Independence, 42 ConN. L. Rev. 1, 40 (2009) (asserting that when attorneys are "motivated to zealously represent their clients, a partisan bias may shade and distort their advice"); Robbennolt \& Sternlight, supra note 190, at 1137-38 (explaining that an adversarial mindset can cause lawyers to take zealousness too far).

192. See Perlman, supra note 190, at 1655-56 (discussing research study in which auditors' determination of whether financial reports were GAAP-compliant was heavily influenced by the partisan role the auditors were asked to play as either retained by the company or by an outside investor and asserting that "lawyers may be particularly vulnerable to this distortion given their institutional function").

193. See generally Perlman, supra note 190, at 1641 ("The research on partisanship strongly implies that lawyers who adopt this view will have difficulty identifying the line between permissible and impermissible advocacy ....".).

194. Robbennolt \& Sternlight, supra note 190, at 1120-21 (arguing that "ethical fading" explains how lawyers frequently respond to a discussion of ethics: they do not think much about ethics, do not see issues in ethical terms, and they "appear to be so acculturated to certain practices they did not consider the ethical issues implicated by those practices").

195. Id. at 1129; Perlman, supra note 190, at 1657 (describing the strong incentive for lawyers to please clients, making it harder to resist "the distorting effects of partisanship").

196. See Eldred, supra note 190, at 765 (explaining situationism as the "general notion that the subtle aspects of a situation often play" a role in decision making, such as the power of a group to exert pressure on an individual to conform or an authority figure to command obedience). 
tations and imposing disciplinary consequences for discovery misconduct. ${ }^{197}$ Ethical conduct is more likely when those ethics issues are in the forefront of attorneys' thought processes. ${ }^{198}$ Judges can make these issues salient by raising the issue of discovery ethics in conferences with attorneys and reinforcing those conversations by putting expectations in writing (such as a scheduling order). ${ }^{199}$ Further, the real, imminent prospect of discipline would impact a lawyer's personal interests, thus influencing how the lawyer interprets information and makes decisions about discovery conduct. ${ }^{200}$ It may only take the imposition of discipline in a case or two in the judge's court for the word to spread and attorneys to adjust their conduct. ${ }^{201}$ Finally, the judge's role as an authority figure and the pressure of obedience could also influence attorney decision making in this context. ${ }^{202}$

\section{ADVANTAGES OF DISCIPLINE OVER SANCTIONS ALONE}

Some might opine that sanctions could be used in this same way (consistently and appropriately) to deter discovery misconduct. People in this camp might argue that if a judge or an entire court were to develop a reputation for sanctioning discovery misconduct, this too could deter misconduct and result in a more efficient discovery process. ${ }^{203}$ Sanctions-only proponents would note that the advantage of using sanctions over discipline is efficiency: the judge presiding over the matter can address the issue without the need to refer the matter to the

197. This focus on the judge's influence is a different perspective from that offered in other behavioral legal ethics literature, which has considered what lawyers, law firms, and rule makers might do to address cognitive biases. See, e.g., Robbennolt \& Sternlight, supra note 190, at 1156-81 (describing steps that attorneys and legal employers should take to address unconscious and unintentional attorney misconduct); Perlman, supra note 190, at 1662-67 (describing how lawyers should utilize debiasing techniques and approaches that lawmakers and regulators might take to lessen the risk of biased decision making).

198. See Robbennolt \& Sternlight, supra note 190, at 1158-59 (suggesting tools lawyers can use to make ethics salient).

199. See infra Part VI.A.

200. See Robbennolt \& Sternlight, supra note 190, at 1129.

201. See, e.g., Ellis \& Hanes, supra note 145, at 16 (reporting a 600\% increase in attorney reports of misconduct in the year following one attorney being disciplined for his failure to report misconduct as required by Illinois RPC 8.3).

202. See Eldred, supra note 190, at 765-66 (citing Catherine Gage O'Grady, Wrongful Obedience and the Professional Practice of Law, 19 J.L. Bus \& EтHICs 9 (2013) and Andrew M. Perlman, Unethical Obedience by Subordinate Attorneys: Lessons from Social Psychology, 36 Hofstra L. ReV. 451 (2007) (noting social psychology research on the power of an authority figure to command obedience)).

203. See generally Nat'l Hockey League v. Metro. Hockey Club, 427 U.S. 639, 643 (1976) (discovery sanctions are intended to deter misconduct); Sec. Nat'l Bank of Sioux City v. Day, 800 F.3d 936, 942 (8th Cir. 2015) (asserting that discovery misconduct would be deterred if more attorneys would seek and more judges would impose discovery sanctions); Mancia v. Mayflower Textile Servs. Co., 253 F.R.D. 354, 360 (D. Md. 2008) (asserting that judges are expected to impose sanctions for counsel's violation of FRCP 26(g) in order to "punish and deter" discovery misconduct); see also Zacharias, Nobody's Watching, supra note 113, at 1003 (considering the availability of other remedies as a reason for not enforcing professional conduct rules). 
court's disciplinary process (or a state disciplinary body) for a satellite proceeding.

As a threshold matter, discipline does not necessarily have to occur in a satellite proceeding. When not prohibited by local rules, ${ }^{204}$ a court could rely upon inherent authority to impose discipline in the context of a pending case. ${ }^{205}$ The judge would need to provide due process protections to the attorney ${ }^{206}$ and undertake the same analysis concerning appropriate discipline as a judge presiding over a disciplinary proceeding. ${ }^{207}$

Nonetheless, even if the norm is a separate disciplinary proceeding-with increased cost and lost efficiency-discipline should not be dismissed out of hand. There are a number of potential advantages to discipline over sanctions alone that are worth considering as courts wrestle with how to address discovery misconduct.

Disciplining attorneys for their discovery misconduct may encourage attorneys to lead rather than follow their clients through discovery. ${ }^{208}$ When sanctions — often only assessed against the client ${ }^{209}$ — are the only penalty of discovery abuse, lawyers may view misconduct as a choice that can be left to the

204. Of course, there are some local rules that explicitly permit the judge to handle discipline in the pending matter. See supra note 117 and accompanying text.

205. See Ryan v. Astra Tech, Inc., 772 F.3d 50, 58-59 (1st Cir. 2014) (determining that District of Massachusetts' local disciplinary procedure is an option for handling attorney discipline and not the only permitted method of imposing discipline); Steward v. Steward, 529 B.R. 903, 918-19 (E.D. Mo. 2015) (finding that the bankruptcy court properly relied upon its inherent authority in suspending attorneys and was not required to institute formal disciplinary proceedings under local rules of the court). Not referring a matter in favor of handling it in the pending case conserves resources, but is likely not appropriate in a case when additional factual investigation is necessary. See infra notes 246-51 and accompanying text (concerning how judges should analyze the issue to determine if referral is unnecessary); infra notes 261-64 and accompanying text (concerning adopting a local rule to give judges guidance about when it is appropriate to handle discipline in a pending case).

206. In re Ruffalo, 390 U.S. 544, 550 (1968) ("[An attorney sought to be disbarred] is ... entitled to procedural due process, which includes fair notice of the charge.”); Fed. Grievance Comm. v. Williams, 743 F.3d 28, 30 (2d Cir. 2014) (describing due process requirements fulfilled in disciplinary proceeding when attorney received adequate notice of the charges and adequate time to defend himself); In re Tutu Wells Contamination Litig., 120 F.3d 368, 418 (3d Cir. 1997) (explaining due process rights that must be provided when court is considering suspending an attorney as including "notice of the legal rule on which the sanctions would be based, the reasons for the sanctions, and the form of the potential sanctions").

207. See infra notes $218-22$ and accompanying text.

208. See Heller v. City of Dallas, 303 F.R.D. 466, 477 (N.D. Tex. 2014) (“[E]ven if the client directs counsel to respond to discovery requests in a certain manner, counsel has the ultimate obligation to ensure that the responses and objections are well grounded in fact and law."). Many attorneys currently have it backwards, believing that clients take the lead in discovery. See, e.g., Granados v. Traffic Bar \& Rest., Inc., No. 13 Civ. 0500 (TPG) (JCF), 2016 WL 1317988, at*2 (S.D.N.Y. Mar. 31, 2016) (attorney argued that sanctions against him should be set aside because he had zealously represented his clients who had not cooperated in discovery).

209. See Willoughby et al., supra note 3, at 815-18 (detailing empirical evidence that clients are sanctioned for discovery misconduct more often than lawyers, and when lawyers are sanctioned, clients are typically sanctioned as well). 
client. $^{210}$ The real prospect of discipline may help attorneys understand that they, and not their clients, will pay professional consequences for violating the discovery rules and related professional conduct rules. If the client refuses to follow the lawyer's lead, the lawyer has an easy and required remedy: withdraw from the representation. ${ }^{211}$

The prospect of discipline is a powerful incentive because it impacts an attorney's license and livelihood. ${ }^{212}$ Obviously, being suspended or disbarred for discovery misconduct would prevent the attorney from practicing. But even less severe forms of discipline have an impact. Public discipline (such as a reprimand) is revealed when a client or prospective client searches for the attorney's name in a state's online attorney directory. Prior discipline, and even the pendency of disciplinary proceedings, can prevent an attorney being admitted pro hac vice in another court. ${ }^{213}$ Further, because an attorney practicing in a federal court is also licensed in one or more states, ${ }^{214}$ an attorney disciplined by a federal court can expect reciprocal discipline of his or her state-issued license. ${ }^{215}$

Funneling misconduct to a federal court's discipline system may help the court recognize the need for (and then, develop) systemic solutions to common problems. ${ }^{216}$ Developing remedial education programs for lawyers who do not properly conduct discovery could be central to a federal court's effort to achieve change. Educating members of the bar who lack an understanding of the law may be a more efficient way to effect change than through sanctions alone. ${ }^{217}$

210. Thomas Y. Allman, Conducting E-Discovery After the Amendments: The Second Wave, 10 SedonA Conf. J. 215, 218 (2009) ("A mild presumption exists that clients are in the best position to control their counsel and, absent egregious counsel conduct, should bear the discovery sanctions.").

211. Model Rules R. 1.16(a)(1) (lawyer shall withdraw from the representation if the representation will result in violation of professional conduct rules); see, e.g., Farmer v. Hyde Your Eyes Optical, Inc., No. 13-CV-6653 (GBD)(JLC), 2015 WL 2250592, at *3 (S.D.N.Y. May 13, 2015) (describing counsel's motion to withdraw based on "deterioration of the attorney-client relationship" shortly after client failed to produce documents he had been ordered to produce).

212. See Freeman, supra note 146 (arguing that discovery abuse happens when the benefits exceed the costs, but that the possibility of discipline under Rule 3.4(d) offers a "drastic means of limiting discovery abuse-targeting the offending lawyer's license").

213. See, e.g., In re Kugel Mesh Hernia Repair Patch Litig., No. MDL 07-1842ML, 2011 WL 4444066, at *2 (D.R.I. Sept. 6, 2011) (pro hac vice admission can be denied based on "applicant's qualifications, character, past conduct and any other factors that bear on the applicant's fitness to practice in this Court" (citing D.R.I. Loc. R. 204(f)(1))).

214. See, e.g., E.D. TENn. Loc. R. 83.5(a)(1) (to be admitted, attorney must be admitted to practice in the highest court of a state, territory, or the District of Columbia).

215. See, e.g., Tenn. Sup. Cт. R. 9, § 25 (Reciprocal Discipline). Likewise, even if discipline for the misconduct originates in the state discipline system, the attorney is subject to reciprocal discipline in the federal courts in which he or she practices. See, e.g., E.D. TENN. Loc. R. 83.7(g) (Conformity with State Discipline).

216. See In re Am. Airlines, 972 F.2d 605, 611 (5th Cir. 1992) (asserting that federal district courts are obligated "to take measures against unethical conduct occurring in connection with any proceeding before [them]" and that they have an obligation to "clean [their] own house").

217. See, e.g., Mahoney v. Yamaha Motor Corp. U.S.A., 290 F.R.D. 363, 372 (E.D.N.Y. 2013) (sanctioning attorney despite his argument that he should not be sanctioned because he is inexperienced). 
Further, using the court's internal discipline system can also facilitate fair consequences for an attorney's discovery misconduct. While the proper level of sanctions is largely left to the discretion of the individual judge, imposing discipline generally requires the disciplinary authority to seek and the judge to impose uniform punishment for similar violations. ${ }^{218}$ Thus, absent aggravating or mitigating factors, an admonition is appropriate for negligent conduct in discovery resulting in little or no injury to another party ${ }^{219}$ while suspension would be appropriate if a lawyer knowingly violates a court rule or order, causing injury to another party or interference with the proceeding. ${ }^{20}$ Appropriate discipline also takes into account prior discipline history. ${ }^{221}$ Thus, if a court's judges make consistent referrals of discovery misconduct, over time, disciplinary authorities will be able to identify lawyers with a history of discipline for discovery misconduct and impose more severe discipline. ${ }^{222}$

Finally, RPC 3.4 represents the values of the legal profession and its enforcement-or non-enforcement-represents the profession's commitment to those values. Rule 3.4 demands that attorneys act competently, openly, and fairly in the interest of the opposing party in discovery. ${ }^{223}$ The title of the rule explicitly references what is at stake: the fair treatment of opposing parties and opposing counsel. ${ }^{224}$ When today's Model Rule 3.4 was proposed by the Kutak Commission in 1982, the bar associations that filed comments opposing the rule argued it was not consistent with the lawyer's duty as an advocate and that frivolous discovery requests and diligent efforts to respond to proper discovery requests were matters of procedure and not professional conduct. ${ }^{225}$

The fact that Model Rule 3.4 was adopted over these objections ${ }^{226}$ and thereafter adopted by the vast majority of jurisdictions ${ }^{227}$ indicates that fair play

218. See generally StANDARDS FOR IMPOSIng LAWYER SANCTIONS (Am. Bar Ass'n 1992) (approved February 10, 1986, amended February 4, 1992).

219. Id. at Standard 6.24.

220. See id. at Standard 6.22.

221. See id. at Standard 9.22.

222. See id.

223. See Model Rules R. 3.4.

224. See Model Rules R. 3.4.

225. A Legislative History: The Development of the ABA Model Rules of Professional Conduct, 1982-2005, at 463-68 (2006) (the Los Angeles County Bar Association commented that the topics covered in proposed paragraph (d) "are not matters governed by Rules of Conduct but rather by Rules of Practice"; the Cuyahoga County Bar Association asserted the effect of the proposed rule "is to destroy advocacy and require[] the lawyer to practice at his or her peril. The proposed rule totally ignores the dynamics of litigation"; the Philadelphia Bar Association urged "[t]he proposed paragraph (d) would move sanctions for discovery abuse from being the responsibility of the trial judge to the disciplinary process").

226. Most of the objections and proposed amendments were withdrawn and others were defeated when the ABA adopted the rule as proposed. See id.

227. See supra notes 102-05 and accompanying text. 
in discovery is an essential value of the legal profession. ${ }^{228}$ This rule fits into the category of professional conduct rules in which the profession has decided lawyers must put the interests of a third party before the desires of a client. ${ }^{229}$ It represents a choice and commitment that lawyers must protect opposing parties in discovery. ${ }^{230}$ This is essential to the workings of a litigation process in which a party must rely upon opposing counsel. ${ }^{231}$ When federal judges ignore the professional misconduct aspect of discovery abuse, they miss an opportunity to uphold the profession's values. ${ }^{232}$ This is a mistake. Referring attorneys for discipline and then imposing discipline for discovery misconduct makes a powerful statement about the principles of our profession.

\section{Discipline-Focused Reforms that MAy IMPROVE Discovery Conduct in Federal Civil Cases}

Ultimately, the attorney discipline system will not deter discovery misconduct absent change in current practices and rules. Reforms could come about by educating federal judges about how and why they can use the discipline system to address discovery misconduct, educating attorneys about discovery conduct expectations at the outset of a case and again if misconduct occurs, and amending local rules and judicial conduct rules to address various discipline-related issues. The following discussion considers how these changes might be accomplished at three levels: by individual judges, at the court-level, and across the federal judiciary.

\section{A. JUDGE-LEVEL REFORMS: SCHEDULING CONFERENCES AND ORDERS AND ADDRESSING MISCONDUCT WHEN IT OCCURS}

Meaningful change in attorney discovery conduct could occur in response to reforms instituted by a single judge. For example, if a U.S. Magistrate Judge who deals with a high volume of discovery disputes each year were to implement discipline-focused changes in his or her courtroom, these changes could have a deterrent effect on misconduct by all attorneys who appear in that courtroom. This Part focuses on two changes individual judges could institute: (1) using scheduling conferences and orders to educate lawyers about expectations and

228. See Alex B. Long, Employment Discrimination in the Legal Profession: A Question of Ethics?, 2016 U. ILL. L. REV. 445, 472 (explaining that a function of professional conduct rules is to disseminate the profession's values).

229. See Paula Schaefer, A Primer on Professionalism for Doctrinal Professors, 81 Tenn. L. Rev. 279, 288-89 (2014).

230. See id. at $288-90$.

231. See supra notes 59-61 and accompanying text.

232. See generally Zacharias, Purposes, supra note 189, at 739 (asserting that when professional conduct rule violations are ignored, attorney misconduct is encouraged and the public may lose trust in the disciplinary system). 
consequences of misconduct, and (2) addressing discovery misconduct when it happens.

\section{SCHEdULIng CONFERENCES AND ORders}

A judge should alert attorneys early in a case of the judge's practice of making discipline referrals for discovery misconduct. This is not a due process issue; the attorneys are already aware that they can be referred for discipline, and they will have a later opportunity to defend themselves against discipline charges. The point of alerting attorneys to the possibility of discipline is to remind attorneys of their professional conduct obligations, and hopefully, to encourage them to comply with those obligations. ${ }^{233}$

Judges should consider providing this information to attorneys at a scheduling conference following the parties' 26(f) discovery planning conference. ${ }^{234}$ Thereafter, the same information should be included in the court's scheduling order. $^{235}$ The 2015 amendments to the FRCP encourage judges to be more hands-on in discovery planning in the scheduling conference. ${ }^{236}$ It is consistent with those amendments for the scheduling conference and order to outline the judge's expectations and the judge's plan to refer attorneys for discipline when they violate professional conduct rules.

A judge will then have to decide how much guidance to provide attorneys about expectations. Just like ineffective boilerplate objections, including a long, boilerplate page of information in every scheduling order will likely be counterproductive. Attorneys will be unlikely to read it or think about how it applies to them. Similarly, a short reminder that RPC 3.4 applies and that attorneys can be referred for discipline if they violate the rule is not enough; such a statement does not alert attorneys to the specific types of discovery conduct they should avoid. ${ }^{237}$

Instead, the judge should think about and address the specific issues that are likely to arise in the case before the judge, as well as common forms of discovery misconduct. With this framework in mind, judges may want to include discussion of several (or all) of the following in their scheduling conferences and scheduling orders:

233. See supra Part V.B (discussing the goals of consistently alerting attorneys to the prospect of discipline for discovery misconduct).

234. See FED. R. Civ. P. 16(b)(1)(A)-(B) (directing the district court to issue a scheduling order after receiving the parties' 26(f) report or after consulting with counsel at a scheduling conference).

235. See FED. R. CIV. P. 16(b)(3) (contents of scheduling order).

236. The 2015 amendments to the rule removed a reference to consulting with the parties "by telephone, mail or other means," clarifying that the scheduling conference should be interactive. FED. R. CIV. P. 16(b)(1)(B) advisory committee's note to 2015 amendment ("A scheduling conference is more effective if the court and parties engage in direct simultaneous communication.").

237. See supra notes $162-79$ and accompanying text (discussing discovery misconduct that should be referred for discipline). 
- Preservation and Spoliation. Judges should discuss with the parties the preservation efforts that have been made to date and additional steps that should be taken, and resolve any disputes between the parties concerning preservation efforts that should be made. ${ }^{238}$ These issues should be memorialized in the scheduling order. ${ }^{239}$ On the issue of discipline, judges should alert attorneys that if evidence is destroyed because of an attorney's non-compliance with preservation efforts described in the scheduling order or required by other sources of law, the court will determine whether the attorney has violated RPC $3.4(\mathrm{a}),{ }^{240}$ and if so, will refer the attorney for discipline.

- Proportionate Discovery. The parties and the judge may be able to agree upon phased or limited discovery (such as initially confining document discovery to a certain number of key players) that is proportionate to the needs of the case. ${ }^{241}$ If such limits are included in the scheduling order, the judge could also direct parties that seeking discovery beyond these parameters without leave of the court may violate the scope of discovery contained in FRCP 26(b)(1) and violate RPC 3.4(c) or (d), which may result in a discipline referral.

- Transparency in Making Specific Objections and Explaining Documents Withheld (or Not Searched for) on the Basis of Those Objections. The judge should remind the parties that the FRCP require objections to be stated with specificity ${ }^{242}$ and require the responding party to state whether any documents are being withheld (or not searched for) on the basis of an objection. ${ }^{243}$ The judge should explain that the judge interprets these rules to mean that attorneys should not use boilerplate or "cut and paste" objections, and that each objection must specifically address the content of the request. Concerning discipline, the judge should explain that if an attorney violates the foregoing rules by (1) making general or boilerplate objections; (2) making objections without stating whether documents are being withheld or not searched for on that basis; or (3) withholding responsive documents without objection or through a misleading

238. See Fed. R. Civ. P. 26(f)(3)(C) (parties' discovery plan should address preservation of ESI); Fed. R. CIV. P. 16(b)(1)(B) (discussing timing of scheduling conference in relation to entry of scheduling order).

239. FED. R. CIV. P. 16(b)(3)(B)(iii) (scheduling order should address preservation of ESI).

240. Model Rules R. 3.4. The references in this Part to RPC sections correspond to provisions of the Model Rules. Judges will need to adapt these references to the version of RPC 3.4 adopted by the court. See supra notes 102-06 and accompanying text.

241. See FED. R. Civ. P. 26(b)(1) (addressing factors relevant to proportionate discovery).

242. See FED. R. Civ. P. 34(b)(2)(B).

243. FED. R. CIV. P. 34(b)(2)(C) ("An objection must state whether any responsive materials are being withheld on the basis of that objection."); FED. R. Civ. P. 34(b)(2)(C) advisory committee's note to 2015 amendment ("An objection that states the limits that have controlled the search for responsive and relevant materials qualifies as a statement that the materials have been 'withheld."”). 
objection, the court will determine whether the attorney violated RPC 3.4(a), (c), or (d) and if so, refer the attorney for discipline. ${ }^{244}$

- Violating Court Orders. The court should note that generally a rule of civil procedure has been violated when an attorney is sanctioned for violating a court order, including this scheduling order and orders compelling production of documents. Accordingly, in any situation when the court sanctions an attorney for violating a court order, the court will also consider whether the attorney has violated RPC 3.4(c) (or any other provision of RPC 3.4), and if so, refer the attorney for discipline. $^{245}$

\section{AdDressing Discovery Misconduct When It Occurs}

The next challenge for a judge is to address discovery misconduct when it occurs. A judge should start by considering whether discipline can be imposed in the pending case, rather than referring the case to the court's formal disciplinary process. First, a judge should consider the court's local rules concerning the discipline system and determine whether those rules permit the judge to handle discipline within the pending case ${ }^{246}$ or prohibit or otherwise place any limits on a judge's ability to impose discipline pursuant to inherent authority. ${ }^{247}$ Assuming the judge can handle discipline within the pending case, the judge next should consider whether he or she should do so. A key consideration should be whether the procedures provided by the court's internal disciplinary system (such as investigation by an attorney or committee) are safeguards needed given the factual and legal complexity of the case. ${ }^{248}$ For example, when the misconduct is fully known to the judge-such as improper objections that violate the FRCP - the added layer of an investigation may not fit the needs of the case. ${ }^{249}$ Prior to imposing discipline, the judge must give the attorney due process protections of notice of possible discipline and an opportunity to defend against

\footnotetext{
244. See Model Rules R. 3.4.

245. See Model Rules R. 3.4.

246. See supra note 117 and accompanying text.

247. See supra note 205 and accompanying text.

248. See Ryan v. Siupa, 772 F.3d 50, 58-59 (1st Cir. 2014) (determining that a court has inherent authority to discipline absent an unambiguous local rule taking away that power, but also noting it is "unlikely that the district court would create such a detailed and resource-intensive [internal disciplinary system] if individual district court judges could decline to follow it").

249. When a judge observes the misconduct that is the basis of discipline, there is a lesser need for procedural protections. See, e.g., In re Ruffalo, 390 U.S. 544, 550 (1968) (“[W]hen proceedings for disbarment are not taken for matters occurring in open court, in the presence of the judges, notice should be given to the attorney of the charges made and opportunity afforded him for explanation and [defense]."); Steward v. Steward, 529 B.R. 903, 919 (E.D. Mo. 2015) ("The bankruptcy court did not need to refer the matter to appointed counsel for 'investigation and prosecution of a formal disciplinary proceeding' [provided by local rule] because the misconduct at issue was directed at and witnessed by the bankruptcy court.”).
} 
that discipline. ${ }^{250}$ Following a hearing on discipline, a court must apply the same standards for imposing discipline that would be imposed in a separate disciplinary proceeding. ${ }^{251}$

If handling discipline in the pending case is not an appropriate or feasible option, the judge should refer the attorney to the court's discipline system. ${ }^{252}$

\section{B. COURT-LEVEL REFORMS: JUDICIAL EDUCATION, ATTORNEY EDUCATION, AND AMENDMENTS TO LOCAL RULES}

A federal court's judges could take a system-wide approach to the issues of discovery misconduct and discipline. Judicial education programs, lawyer education programs, and local rule amendments are some avenues that a federal court may want to explore.

\section{Education Programs for Judges}

A continuing legal education program for judges, law clerks, and staff is an ideal time to consider the topic of discipline for discovery misconduct. The program should include the basics regarding applicable professional conduct rules, ${ }^{253}$ reporting rules applicable to judges, ${ }^{254}$ and the court's discipline system. $^{255}$ The discussion should consider the possible benefits of more consistent, appropriate discipline referrals. ${ }^{256}$ Judges could be provided with examples from recent cases of attorneys who could have been referred for discipline and the likely outcome if that referral had been made.

Likely the most important part of this program is a discussion of the judges' own experiences. Judges and law clerks should be encouraged to discuss whether the 2015 amendments to the FRCP are making a difference in discovery practice in the court, examples of discovery misconduct they have observed, and the reasons they do (or, more likely, do not) refer attorneys for discipline. It would be useful for a presenter to compile the court's statistics over the previous twelve months: motions to compel filed (and granted), motions for sanctions filed (and granted), discipline referrals for discovery misconduct, and attorneys disciplined for discovery conduct. This discussion may reveal the extent of the discovery problem, misconceptions about discipline, as well as legitimate concerns that the court could address to facilitate discipline referrals.

\footnotetext{
250. See supra note 206 and accompanying text.

251. See supra notes $218-22$ and accompanying text.

252. See supra note 118 and accompanying text (noting courts with and without internal discipline systems).

253. See supra notes 102-06 and accompanying text (regarding federal courts' adoption of professional conduct rules and regarding state versions of RPC 3.4).

254. See Code of Conduct for U.S. Judges, Canon 3(B)(5).

255. See supra notes $117-18$ (regarding federal courts' discipline systems).

256. See supra Part V.
} 


\section{Remedial Discovery Education Programs to Address Lawyer Misconduct}

Courts should also develop remedial discovery education programs for attorneys who violate discovery rules. Attorneys could be referred to such a program as part of a diversion program or as a form of discipline. Courts should consider the educational advantages of providing attorneys with hands-on opportunities to correct the types of mistakes that landed them in the diversion program. For example, attorneys referred to the program for violating rules governing discovery objections could be required to participate in a class on proper objections and then revise their own objections and responses. ${ }^{257}$ Local rules, discussed next, could facilitate judges directing attorneys to this program.

\section{Amendments to Local Rules that Facilitate Discovery Discipline and EDUCATION}

A court-wide discussion may reveal procedural barriers to judges fully utilizing the discipline system to address discovery misconduct. Such issues could be addressed through new or amended local rules. ${ }^{258}$ Most U.S. district courts already have local rules adopting professional conduct rules and attorney discipline systems, but for courts that do not, adopting local rules to create such a system should be considered. ${ }^{259}$ Other possible local rules are addressed below.

Judges may choose not to refer attorneys for discipline if they perceive that making the referral will be time consuming. ${ }^{260}$ A local rule could simplify (or clarify) the process for making a discipline referral to the court's internal disciplinary system. The rule could provide: "A referral for discipline may be stated within any court order in which the court determines an attorney has engaged in conduct that may violate a professional conduct rule."

A court could also adopt a local rule addressing when a judge should handle discipline as part of a pending case rather than referring the case to the court's disciplinary system. ${ }^{261}$ In crafting such a rule, the court should consider the procedures included in its internal discipline system and decide when using those procedures is more cumbersome than necessary to protect the rights of the attorney and further the goals of imposing discipline. As a result of this process, a

257. See supra notes 62-63 and accompanying text (explaining rules governing proper objections and the need to describe documents withheld from discovery).

258. Federal courts have the authority under the Rules Enabling Act to adopt local rules governing court business. See 28 U.S.C. $\$ 2071$ (a) (2012). Local rules may be adopted after a public notice and comment period and need not be submitted to Congress (as required for the FRCP). See 28 U.S.C. §§ 2071(b), 2074; FED. R. CIV. P. 83(a) (describing district court process for adopting local rules).

259. See supra note 117 and accompanying text.

260. See supra notes $158-59$ and accompanying text.

261. Arguably, the court has inherent authority to discipline within the pending case absent local court rules explicitly taking away that authority. See supra note 205 . The point of a local rule would be to remind judges that they can exercise that authority and to guide them in determining when it is appropriate to do so. 
court may adopt a local rule providing the judge should impose discipline in the pending case when: (1) there is a lack of factual complexity (such as when the judge observed the misconduct or is otherwise fully aware of the facts relevant to a finding of misconduct), ${ }^{262}$ and (2) when the attorney has no prior discipline record and the misconduct is properly punishable by discipline less than suspension. ${ }^{263}$ Finally, the rule should also explain the procedural protections that the attorney should be provided when discipline is handled in a pending case, such as issuing a show cause order that gives notice of the reasons discipline is being considered and the specific discipline contemplated, and provide a defined period of time for the attorney to respond in writing prior to a hearing on the matter. $^{264}$

There are two ways local rules could make lawyer education programs a part of the court's discipline system. A court could adopt a local rule that permits an attorney to enter a diversion program for minor offenses. ${ }^{265}$ Participation in an education program should be explicitly referenced as a means of satisfying a diversion agreement. ${ }^{266}$ Another option would be to list participation in an education program as a possible form of discipline. ${ }^{267}$ Even without such a local rule, a court could order education as discipline pursuant to a catchall provision allowing a judge to fashion appropriate discipline ${ }^{268}$ or pursuant to inherent authority. ${ }^{269}$ Nonetheless, having an explicit reference to education in a local rule

262. This element addresses the concern that an investigation may not be necessary when the judge is fully aware of the misconduct. See supra notes $248-49$ and accompanying text.

263. This element is meant to lessen concerns of addressing more complex discipline decisions involving prior offenses as an aggravating factor or more severe forms of discipline. See ABA STANDARDS FOR IMPOSING LAWYer SANCTIONS, at Standard 9.3.

264. See generally supra note 206 (discussing procedural due process requirements in discipline proceedings).

265. Diversion rules seem to be somewhat rare in federal court local rules. See, e.g., supra note 123. Rules addressing diversion are common in state professional conduct rules. See, e.g., N.J. CT. R. 1:20-3 ("If, as a result of investigation, the chair concludes that minor unethical conduct has occurred, the chair may request that the Director, or his designee, divert the matter and approve an agreement in lieu of discipline.").

266. For example, the New Jersey diversion rule referenced in the previous note specifically lists "satisfactory completion of a course of study" as a possible requirement for satisfaction of diversion. N.J. Cт. R. $1: 20-3$.

267. See, e.g., W.D. WASH. Loc. R. 83.3(c)(4)(F) (“Any discipline imposed may be subject to specific conditions, which may include, but are not limited to, continuing legal education requirements, counseling and/or supervision of practice.").

268. See, e.g., E.D. TenN. Loc. R. 83.7(a) ("Discipline which may be imposed includes disbarment, suspension, reprimand, or such other further disciplinary action as the Court may deem appropriate and just.") (emphasis added); MASs. DisT. Loc. R. 83.6.4 ("An attorney may be subject to the following types of discipline after a finding of misconduct pursuant to these rules ... such other disciplinary action as may be reasonable under the circumstances.") (emphasis added); D. NEB. Loc. R. 1.8(g)(2) (“An attorney subject to the court's disciplinary jurisdiction may be disbarred, suspended from practice before the court, reprimanded, or subjected to other appropriate disciplinary action.") (emphasis added).

269. See generally In re Marshall, No. 3:15-MC-88-JWD, 2016 WL 81484, at*1 (M.D. La. Jan. 6, 2016) (suspending attorney and ordering completion of six hours of ethics continuing legal education). 
would provide a reminder of the availability of the option, thus encouraging its use.

\section{FEDERAL JUDICIARY-WIDE REFORM: ADOPTION OF A MANDATORY DISCIPLINE REFERRAL RULE IN THE CODE OF CONDUCT FOR U.S. JUDGES}

Strengthening rules requiring discovery misconduct reporting to disciplinary authorities is another approach that might be taken to address discovery discipline. However, for reasons discussed below, this is likely the least effective avenue to meaningful change in discovery conduct.

Rules requiring defined discovery misconduct to be referred to disciplinary authorities would likely result in more discipline (or diversion), and ultimately, might deter the most serious forms of discovery misconduct. Through local rules, individual courts could strengthen the professional conduct rules requiring attorneys to report discovery misconduct by other attorneys. ${ }^{270}$ However, judges are equally well positioned to know about counsel's discovery misconduct, and judges face fewer adverse consequences than attorneys if they report the misconduct. ${ }^{271}$ For this reason, a better approach would appear to be strengthening the judicial reporting rule.

As discussed in Part IV, the current Code of Conduct for U.S. Judges requires federal judges to take "appropriate action" to address attorney misconduct but does not mandate reporting to disciplinary authorities. ${ }^{272} \mathrm{~A}$ viable approach would be to mandate judges to refer attorneys to disciplinary authorities for defined forms of discovery misconduct. Currently, California mandates judicial reports of attorney misconduct to the state bar when certain trigger events occur. ${ }^{273}$ Ironically, even though California requires bar notification of sanctions against an attorney, the provision specifically excludes sanctions against an attorney for "failure to make discovery." 274

The difficult part, then, is deciding what conduct should trigger mandatory reporting under an amended rule. One approach would be to mandate a

270. See supra note 258 and accompanying text (describing authority to adopt local rules).

271. See Greenbaum, supra note 136, at 544 (asserting that there are more reasons for lawyers than there are for judges to avoid reporting attorney misconduct).

272. Code of Conduct For U.S. Judges, Canon 3(B)(5).

273. See Cal. Bus. \& Prof. Code $§ 6086.7$ (the statute provides that a court shall notify the California state bar of: (1) contempt against an attorney (that may involve grounds warranting discipline); (2) a modification or reversal of a judgment based in whole or part upon misconduct, incompetence, or willful misrepresentation by an attorney; (3) sanctions against an attorney (except "for failure to make discovery" or for less than \$1,000); (4) a civil penalty under a certain provision of California's Family Code; and (5) a defined violation of California's penal code by a prosecuting attorney under circumstances involving bad faith and impacting the rights of an accused); see also Arthur F. Greenbaum, The Automatic Reporting of Lawyer Misconduct to Disciplinary Authorities: Filling the Reporting Gap, 73 Онго Sт. L.J. 437, 467-71 (2009) (explaining California's statute as including the most extensive set of systemic obligations to report occurrences of particular acts to disciplinary authorities).

274. Cal. Bus. \& Prof. Code $§$ 6086.7(a)(3). 
disciplinary referral if the court finds that an attorney violated court rules governing discovery. The advantage of this approach is simplicity. But the disadvantage is that it would result in both over-reporting of misconduct (such as where the attorney did not "knowingly" violate court rules, and thus would not be in violation of RPC 3.4) and the underreporting of misconduct (such as where the attorney engaged in intentional spoliation of evidence, which is not a violation of a court rule).

Another approach would be to mandate a disciplinary referral when a court sanctions an attorney (and not just a client) under the authority of FRCP 26(c), $26(\mathrm{~g})$ or 37 , or the court's inherent authority. The advantage of this approach is that it is simple to implement and (arguably) captures the most serious forms of attorney misconduct. However, there are some significant problems with this approach. One is that pervasive forms of attorney misconduct may regularly fall outside of the mandate, such as an attorney's negligence in advising clients about preservation or an attorney's use of boilerplate objections. Another disadvantage is that it might cause courts to err on the side of not sanctioning attorneys, recognizing the sanctions would subject the attorney to discipline. ${ }^{275}$ Finally, given the fact that courts already sanction clients more often than attorneys, ${ }^{276} \mathrm{a}$ good deal of attorney misconduct would continue to fall outside of mandatory reporting.

There is not an obvious answer to how a mandatory reporting rule should be formulated. Perhaps this is why ultimately, this approach is not as workable as reforms by individual judges and courts. Nonetheless, if a mandatory reporting rule were adopted, federal judges and the Judicial Conference would need to commit to continuously studying the rule's effectiveness and making further amendments as needed to address its shortcomings.

\section{CONCLUSION}

Federal courts have largely ignored the disciplinary system as a tool to address and deter document discovery misconduct. If attorney discipline were used appropriately and consistently, federal courts could see an improvement in discovery practice. Appropriate discipline does not stifle zealous advocacy; it facilitates it. An attorney would not face discipline for being on the losing side of a discovery dispute. Rather, discipline is generally only appropriate when an attorney misleads an opponent in discovery or intentionally or negligently fails to perform a duty owed to an opposing party. Consistently educating attorneys about expectations in this regard and consistently using the discipline system when attorneys engage in misconduct could change behavior. Unlike the often

275. This is a significant concern given the authority to sanction the client and not the attorney. See, e.g., FED. R. Civ. P. 26(g)(3), 37(a)(5)(A), 37(b)(2)(C)); supra Part IV.

276. See Willoughby et al., supra note 3 , at $815-18$. 
shared burden of sanctions, attorneys alone will feel the professional consequences of discipline. This should provide an incentive for attorneys to lead (and not follow) their clients through discovery. And imposing discipline for discovery misconduct would remind attorneys that fair play in discovery is an important value of the legal profession.

Ultimately, the most effective avenues to reform likely lie with the judges and courts that deal with discovery misconduct on a day-to-day basis. Individual judges can choose to take a more active role in educating lawyers about the consequences of misconduct and then impose disciplinary consequences when lawyers break the rules. Further, U.S. district courts may successfully encourage court-wide use of the discipline system through conversations among the court's judges and adoption of local rules that make the discipline system more efficient and effective. While it is impossible to know if such reforms would make a significant impact, it is certain that document discovery will remain dysfunctional if courts continue on the current course. 